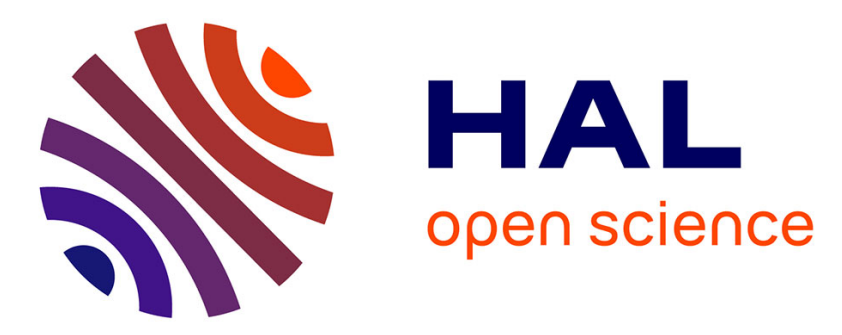

\title{
Paleoclimatic context of geomagnetic dipole lows and excursions in the Brunhes, clue for an orbital influence on the geodynamo?
}

Nicolas Thouveny, Didier L Bourlès, Ginette Saracco, Julien Carcaillet, Franck Bassinot

\section{To cite this version:}

Nicolas Thouveny, Didier L Bourlès, Ginette Saracco, Julien Carcaillet, Franck Bassinot. Paleoclimatic context of geomagnetic dipole lows and excursions in the Brunhes, clue for an orbital influence on the geodynamo?. Earth and Planetary Science Letters, 2008, 275 (3-4), pp.269-284. 10.1016/j.epsl.2008.08.020 . hal-01419595

\section{HAL Id: hal-01419595 \\ https://hal-amu.archives-ouvertes.fr/hal-01419595}

Submitted on 4 Jan 2017

HAL is a multi-disciplinary open access archive for the deposit and dissemination of scientific research documents, whether they are published or not. The documents may come from teaching and research institutions in France or abroad, or from public or private research centers.
L'archive ouverte pluridisciplinaire HAL, est destinée au dépôt et à la diffusion de documents scientifiques de niveau recherche, publiés ou non, émanant des établissements d'enseignement et de recherche français ou étrangers, des laboratoires publics ou privés. 


\title{
Paleoclimatic context of geomagnetic dipole lows and excursions in the Brunhes, clue for an orbital influence on the geodynamo?
}

\author{
Nicolas Thouveny ${ }^{\mathrm{a},} \square$, Didier L. Bourlès ${ }^{\mathrm{a}}$, Ginette Saracco ${ }^{\mathrm{a}}$, Julien T. Carcaillet ${ }^{\mathrm{a}, \mathrm{b}}$, F. Bassinot ${ }^{\mathrm{c}}$ \\ a CEREGE, Aix-Marseille Université et CNRS, Europôle Méditerranéen de l'Arbois, BP 80, 13545, Aix en Provence, cedex 4, France \\ ${ }^{\mathrm{b}}$ Laboratoire de Géodynamique des Chaînes Alpines (LGCA), Université Joseph Fourier et CNRS, BP53, 38041 Grenoble cedex 09, France \\ c Laboratoire des Sciences du Climat et de l'Environnement, CNRS-CEA, Avenue de la Terrasse, 91198, Gif/Yvette, France
}

\author{
Keywords: \\ geomagnetic dipole lows \\ excursions \\ cosmogenic isotope overproduction \\ dating \\ correlation \\ paleoclimates \\ astronomical precession \\ obliquity \\ geodynamo
}

\begin{abstract}
The hypothesis of an influence of the astronomical precession on the geodynamo energy budget was recently reappraised by theoreticians. Paleomagnetic indications of such an influence remain controversial because reconstructions of paleointensity variations from sediments are suspected to be contaminated by lithological: paleoclimatically induced influences. Three sets of complementary indicators are however available: 1) records of the direction of magnetization in sediments, 2) records of magnetic anomalies of the deep sea floor basalts and 3) records of production variations of cosmogenic isotopes from sediment and ice cores. These records confirm the genuine geomagnetic origin of paleointensity lows and their narrow link with excursions or short reversals recorded in various materials and often dated by radiometric methods. The analysis of these time series and their comparison with $\delta^{18} \mathrm{O}$ records of the paleoclimate suggest that such globally recorded geomagnetic dipole lows have preferentially occurred in the context of interglacial or transitional paleoclimates at the time of low or decreasing obliquity. The dominant periods, extracted with the complex continuous wavelet transform technique, range from 40 to $125 \mathrm{ka}$, further suggesting a link with orbital parameters. These results encourage future efforts of research to improve the precision, the resolution and the dating of the time series of geomagnetic dipole low, in order to better decipher orbital signatures and understand their origin. An important implication of this topic is that the next geomagnetic dipole low should be related with the present interglacial.
\end{abstract}

\section{Introduction}

The Earth's magnetic field generation is attributed to a self-excited dynamo process, maintained by the active convection of electrically conducting fluids in the outer core modified by the Earth's rotation (e.g. Glatzmaier and Roberts, 1995), and by a tidally-driven periodic forcing of the core boundary and by a shearing stresses due to the Earth's axis precession, conditions known to produce rotational parametric instabilities (e.g. Aldridge et al., 1997; Aldridge and Baker, 2003).

After Poincaré's (1910) and Bullard's (1949) suggestions, Malkus $(1963,1968)$ proposed that the internal Earth's magnetic field could be maintained by the luni-solar precession, i.e. by a motion of the core relative to the mantle, able to generate frictions transferring mechanical, or magnetic, energy into the conducting fluids of the outer core. Calculations then suggested that precession could produce only $10 \%$ of the energy supposed to be required to maintain the geodynamo (Rochester et al., 1975; Loper, 1975).

Corresponding author.

E-mail address: thouveny@cerege.fr (N. Thouveny)
Geodynamo generation mechanisms became better understood with numerical modeling and experimental systems involving highly

conducting liquids, usually liquid sodium, in rotating containers. Vanyo (1991) showed that former calculation by Rochester et al. (1975) and Loper (1975) had largely underestimated the energy of the precession New numerical experiments have re-evaluated this energy (Vanyo and Dunn, 2001; Roberts and Wu, 2005). The power required to drive the geodynamo also appears to be smaller than previously estimated (Christensen and Tilgner, 2004). Experiments contributed in showing that the flow geometry generated in a rotating and precessing spheroidal envelope filled with water, is similar to the flow in the outer core inferred from geomagnetic secular variation (Vanyo, 2004) Finally, numerical reconstructions of the dynamo effect of a precessiondriven flow in a spherical container (Tilgner, 2005) showed that i) laminar and unstable flows maintain the dynamo; ii) for low ratios of viscosity/geostrophic forces (i.e. low Ekman numbers), the dynamo predominantly relies on the flow components excited by instabilities; iii) the periods of motion are equal to the rotation period of the boundaries; iv) a magnetic dipole moment undergoes slow variations interrupted by reversals. Roberts and Wu (2005) gave the most synthetic and positive opinion on this issue: "all that has been unequivocally established in the intervening $55 \mathrm{yr}$ is that precession can in principle supply the 
geodynamo with abundant power. The question of whether the geodynamo draw on this power is still unanswered, though it seems probable from the work of Tilgner (2005)".

Attempts to extract information from paleomagnetic records started in the late 70s: using the protocol of Levi and Banerjee (1976), Kent and Opdyke (1977) constructed a relative paleointensity (RPI) record for the last $700 \mathrm{ka}$ by dividing the natural remanent magnetization (NRM) intensities by the anhysteretic remanent magnetization (ARM) intensities measured along a core. They interpreted an emerging $43 \mathrm{ka}$ period as the sign of a modulation of a precession-driven dynamo by changes of the Earth's axis tilt (obliquity) and noted that a future confirmation of such observation (i.e. correlation between geomagnetic paleointensity and obliquity) should evidence the contribution of forces arising from the Earth's precession to the geodynamo. Considering the "good evidence that long term climatic variations have been controlled at least in part by Earth's orbital parameters", they added that "a correspondence between some component of climatic change and variations of the Earth's magnetic field could be expected". The suggestion that geomagnetic excursions could be related to global ice volume and Earth's eccentricity (Doake, 1977 and Rampino, 1979) laid on non-normalized magnetic intensity records, which imposed a first bias. Kent (1982) denounced the "apparent correlation of paleomagnetic intensity and climatic records in deep sea sediments resulting from a pronounced dependence of NRM intensity on sediment composition" and concluded that "a weak positive correlation between the NRM/IRM ratio and $\mathrm{CaCO}_{3}$ " can be "optimistically related to some geomagneticclimatic dependence or more likely to an inadequacy in the normalization by IRM to take into account fully the strong lithological effect on the NRM". Various strategies were then employed to attempt improving the reliability of RPI records. Selective criteria for the reliability of the normalization by susceptibility, IRM and ARM were proposed (King et al., 1983). Re-deposition of sediments under a controlled magnetic field was attempted (e.g. Tucker, 1981) and tested (e.g. Thouveny, 1987). Other improvements used progressive alternating field (AF) demagnetization of ARM and IRM in a pseudo-Thellier approach (Tauxe, 1993; Tauxe et al., 1995; Valet and Meynadier, 1998; Valet, 2003). Attempts to further diminish or remove residual effects of grain size or magnetic mineralogical variation were carried out (e.g. Williams et al., 1998) but did not significantly modify the structure of the signals. Models and experiments developed by Tauxe et al. (2006) suggested that environmental factors controlling the flocculation of magnetic particles in saline environments influence the depositional remanent magnetization acquisition and play a critical role in determining reliability and accuracy of normalization methods. Consequently, similarities persisting between environmental records and normalized intensity records systematically lead to question the reliability and the geomagnetic significance of RPI records and lead to develop physical and analytical techniques to improve the criteria for selecting the most accurate normalization parameters (Hofmann and Fabian, 2007; Fabian et al., 2008)].

Spectral analyses of individual or stacked normalized intensity signals often evidenced that the maximum variance is more or less assignable to orbital parameter frequencies. This led to consider that such "orbitally affected" paleomagnetic records suffer from significant biases imposed by lithological and/or paleoenvironmental changes (i.e. magnetic grain size, magnetic mineralogy, maghemitization). For example, Channell et al. (1998), analyzing the NRM/ARM and NRM/ IRM signals along the last $700 \mathrm{ka}$ of ODP holes 983 and 984 (North Atlantic) attributed the dominant $100 \mathrm{ka}$ period to the lithological changes under the influence of glacial-interglacial alternations. However, admitting that the other significant period (41 ka) present in the normalized magnetic intensity signal but absent from paleoenvironmental records, could not be easily explained in terms of lithological changes, these authors concluded that "orbital obliquity affects the geomagnetic field intensity, presumably due to the effect of obliquity on precessional angular velocity and hence on precessional forces in the Earth's core". Kent (1999) concluded from a similar observation for an "evidence for orbital forcing of the geomagnetic field".

A dominant 100 ka period was found in RPI records from the Pacific Ocean (Yokoyama and Yamazaki, 2000). The absence of this period in the normalizing parameter (IRM) record supported the "possibility of an external energy supply of the geodynamo variation through orbital forcing or climate change". This observation, initially limited to the last $700 \mathrm{ka}$, was extended to the last $2 \mathrm{Ma}$ for inclination (Yamazaki and Oda, 2002) and RPI variations (Yokoyama et al., 2007). NRM inclination variation in the Equatorial band record reversals, excursions, and paleosecular variation and have no reason to be biased by lithological changes. The latter are moreover paced by the $41 \mathrm{ka}$, and not by the $100 \mathrm{ka}$, period in this time interval.

Fuller (2006) compared paleointensity records, excursions and reversals with obliquity variations, over various time ranges and reached radically different clues: 1) the strongest RPI minima of the last $800 \mathrm{ka}$ correlate with obliquity minima, 2) polarity intervals shorter than $100 \mathrm{ka}$ occur at 30-40 ka periods, "marginally shorter than the obliquity period", 3) reversals preferentially occurred when the average amplitude of the obliquity is low, 4) the most recent reversals occurred near the inflection point of the descent slope from obliquity maxima (verified for most of the reversals of the last $4 \mathrm{Ma}$ except the boundaries of the Olduvai event), 5) the last nine reversals have a non-random phase relation to the obliquity signal, 6) the dating of older reversals is not accurate enough: an error of $0.33 \%$ is sufficient to destroy the relationship. Testing the relationship between the obliquity and eccentricity phases and the ages of reversals or excursions, Xuan and Channell (2006) have confirmed that reversals of the last $5 \mathrm{Ma}$ preferentially occurred during decrease of the maximum obliquity envelope.

Other studies found no orbital periods or demonstrated their artificial origin. Kent and Carlut (2001) did not find any "discernible tendency of the reversals of the last 5.3 Ma to occur at consistent amplitude or phase of obliquity nor eccentricity". Analyzing the Sint800 curve, Guyodo and Valet (1999) concluded that no significant stable periodicity could be retained, not even a $100 \mathrm{ka}$ period emerging in the 400-800 ka BP interval. Analyzing the $1.1 \mathrm{Ma}$ RPI record of ODP site 983, Guyodo et al. (2000) revealed periods near the eccentricity and obliquity periods but interpreted that as due to a lithological bias. Horng et al. (2003) and Roberts et al. (2003) did not find any statistically significant $100 \mathrm{ka}$ cycle in the $2.2 \mathrm{Ma}$ long Caroline basin record of Yamazaki and Oda (2002). They also denied the influence of eccentricity because the $400 \mathrm{ka}$ period typical of orbital eccentricity was not present. Most recently, several studies led to contradicting conclusions. Heslop (2007) investigated the Sint-800 and SPECMAP curves with a continuous wavelet transform routine and concluded that periods ranging between orbital periods did not reveal significant orbital or paleoclimatic influences on the geomagnetic spectrum. Xuan and Channell (2007) applied power spectral analysis and continuous wavelet analysis to four relative paleointensity (RPI) records and their normalizer records covering the last $2 \mathrm{Ma}$ selected in the North Atlantic and North Pacific oceans. They concluded that orbital cycles (significant power at $100 \mathrm{kyr}$ and $41 \mathrm{kyr}$ periods) detected in these paleointensity records are due to incomplete normalization of the natural remanent magnetization (NRM) records for changes in magnetic concentration and grain size. They pointed out however that since "RPI records can be satisfactorily correlated across differing climatic regimes" and since "filtering orbital power from the time series does not appreciably alter the RPI records", the lithologic contaminations do not debilitate the paleointensity records. Despite such a reassuring conclusion, such RPIpaleoclimate relationships as observed by Xuan and Channell (2007) recall a tendency denounced by Channell (1999) "for paleointensity lows to correlate with peak interglacials". The labeling system proposed by Lund et al. (2006), relating excursions and RPI lows of the ODP 1062 record with the contemporary paleoclimate trend, 
revealed the dominance of odd-numbered excursions, suggesting a narrow relationship with interglacial episodes. If such relationships, concerning such major features are due to lithological contamination, one cannot declare that the "lithologic contaminations do not debilitate the paleointensity records" and one can readily reject the geomagnetic significance.

In the present article, we first examine the reliability of geomagnetic moment proxy records by:

1) comparing relative paleointensity variations (RPI) with cosmogenic nuclide production variations reconstructed from the same cores (e.g. Carcaillet et al., 2003, 2004a,b).

2) comparing the virtual axial dipole moment (VADM) stack Sint-800 (Guyodo and Valet, 1999) with the sea floor magnetization intensity record (Gee et al., 2000).

3) integrating paleomagnetic excursions reported for the Brunhes epoch in the geomagnetic dipole moment lows series.

We will then analyze the timing of geomagnetic dipole moment lows and excursions in the context of glacial/interglacial alternations documented by $\delta^{18} \mathrm{O}$ records.

Finally we evaluate and discuss the possible relations with orbital periods.

\section{Geomagnetic dipole lows and excursions of the Brunhes chron}

According to studies of various rock-types sampled worldwide the normal polarity of the Brunhes chron is affected by a priori different types of instabilities. Initially, the concept of "excursion" was by convention linked with departures of the paleomagnetic vector by more than $40^{\circ}$ away from the direction of the average field assignable to a geocentric axial dipole. However this concept is too often confused with that of "polarity event" which conventionally designates complete and worldwide identified short reversals. This criterion of "globality" yet depends on the geographical distribution of paleomagnetic records available for a given time interval, which is itself constrained by the distribution of studied deposits. The criterion of duration and amplitude are biased by intrinsic properties of the recording material (i.e. sediment lock-in depth, duration and continuity of volcanic emissions) and by sampling and measurements conditions affecting the temporal resolution. In fact, a "polarity event", like a short chron, should be framed by two distinguishable paleointensity drops separated by a legible return to high intensities.

An ongoing debate about the distinction between the two youngest, and most seriously documented, excursions illustrates the ultimate difficulty of establishing an exhaustive and accurate directory of the Brunhes excursions.

- Quasi-reversed magnetizations of the Laschamp and Olby lavas (Chaîne des Puys, France) introduced the hypothesis of a recent short reversal (Bonhommet and Babkine, 1967; Bonhommet and Zahringer, 1969) later dated between 40 and $50 \mathrm{ka} \mathrm{BP}$ (e.g. Gillot et al., 1979). This so-called "Laschamp event" was later found to be linked with extremely weak absolute paleointensities (Roperch et al., 1988). Its traces were searched and found in sedimentary deposits of Maar lakes of the same region: amplified secular variation swings or quasireversed paleomagnetic directions accompanied by weak relative paleointensities (RPI) appeared in layers dated at $\sim 37 \mathrm{ka}$ corrected ${ }^{14} \mathrm{C} \mathrm{BP}$ (Thouveny et al., 1990; Thouveny and Creer, 1992; Thouveny et al., 1993; Vlag et al., 1996). Marine sediment records contributed to confirm its wide extension and set its age (Guyodo and Valet, 1996) The correlation of the NAPIS record (Laj et al., 2000) to the GRIP ice core ${ }^{36} \mathrm{Cl}$ record (Wagner et al., 2000) provided a precise age of $\sim 41 \mathrm{ka}$ BP. Low RPI and excursional directions assigned to the Laschamp were then evidenced in sequences of the north Atlantic (Channell,
1999; Lund et al., 2005), south Atlantic (Channell et al., 2000) and south Indian Ocean (Mazaud et al., 2002).

- The other historical and exemplar discovery of excursion was made in lake sediment deposits of western North America, at Mono Lake (Denham and Cox, 1971; Liddicoat and Coe, 1979), Summer Lake (Negrini et al., 1984) and Lake Lahontan (Liddicoat, 1992, 1996). First dated at $\sim 24$ ka BP (Denham and Cox, 1971; Coe and Liddicoat, 1994), the Mono Lake excursion was re-dated between 26 and $30 \mathrm{ka}$ BP (Lund et al., 1988) and near $32 \mathrm{ka} \mathrm{BP}$ (Negrini et al., 2000). Out of the Western U.S. region, directional and low RPI features were recorded between 32 and $16 \mathrm{ka}$ BP in the Baffin Bay sedimentary sequence and tentatively correlated with the Mono Lake excursion (Thouveny, 1988). The low RPI episode documented by Liddicoat and Coe (1979) was related to a cosmogenic ${ }^{36} \mathrm{Cl}$ enhancement documented at $32 \mathrm{ka}$ BP in the GRIP record (Wagner et al., 2000). The dating of ash layers framing the excursion at Wilson Creek (Kent et al., 2002) surprisingly provided ages ranging from 38 to $41 \mathrm{ka} \mathrm{BP}$, suggesting that the excursion recorded at Mono Lake is the Laschamp excursion. Despite new dating and new attempts of correlation of the Mono lake paleoclimatic proxy record to the Greenland record (Zic et al., 2002; Benson et al., 2003), the recent correlation of the Mono lake RPI stack (Zimmerman et al., 2006) to the GLOPIS record of Laj et al. (2004) supports this identification. Finally recent detailed studies (e.g. Channell, 2006; Blanchet et al., 2006; Leduc et al., 2006) document a highly complex behaviour of the geomagnetic moment between 30 and $45 \mathrm{ka} \mathrm{BP}$.

This debate highlights the need to strengthen paleomagnetic characterizations of each excursion by studying various rock facies and numerous sediment sequences. It also evidences the necessity to perform multiple and methodologically independent dating of each paleomagnetic excursion preferably from various recording materials. Ultimately it shows that each chronological windows supposed to contain an excursion should be investigated to decipher the cosmogenic nuclide overproduction triggered by the dipole field reduction. Former studies of sedimentary cores (e.g. Raisbeck et al., 1985) and ice cores (e.g. Raisbeck et al., 1987), demonstrated that reversal and excursions led to cosmogenic nuclide overproduction. Other studies (e.g. Henken-Mellies et al., 1990) however suggested that such results were neither systematic nor significant. These evidenced that environmental parameters, like the deposition rate. have to be considered prior to selecting the studied sites. Recently, we attempted to decipher the cosmogenic nuclide signatures on sediment cores jointly studied for paleomagnetic identification of low RPI and excursions. The Portuguese margin record was constructed on paralle] cores covering the last 300 ka with sedimentation rates of 10 to $20 \mathrm{~cm}$ / ka (Thouveny et al., 2004; Carcaillet et al.; 2004a). The West Equatorial Pacific records cover two time intervals with different sedimentation rates: the interval 20 to $80 \mathrm{ka} B P$ with $\sim 50 \mathrm{~cm} / \mathrm{ka}$ (Blanchet et al., 2006; Leduc et al., 2006) and the interval 600 to $1300 \mathrm{ka} \mathrm{BP}$ (Carcaillet et al., 2003) with $\sim 3 \mathrm{~cm} / \mathrm{ka}$.

By analogy with NRM normalization principles, the reconstruction of pristine cosmogenic production rate variations requires to correct the concentration of cosmogenic ${ }^{10} \mathrm{Be}$ for the effects of terrigenous flux variations. The ${ }^{9} \mathrm{Be}$ which has a lithogenic origin and the same chemical behaviour as ${ }^{10} \mathrm{Be}$, is considered as the most appropriate normalizer. Indeed, variations of erosion and transport of terrigenous materials not only provoke variations of the input of solubilized ${ }^{9} \mathrm{Be}$ but also variations of the adsorption capacity on the settling particles of the solubilized ${ }^{10} \mathrm{Be}$. Thus the authigenic ${ }^{10} \mathrm{Be} /{ }^{9} \mathrm{Be}$ ratio (i.e. adsorbed on the settling particles), corrects effects of variable terrigenous fluxes and allows reconstructing the cosmogenic ${ }^{10} \mathrm{Be}$ production rate variations (e.g. Carcaillet et al., 2004a,b; Leduc et al., 2006). A calibration of the ${ }^{10} \mathrm{Be} /{ }^{9} \mathrm{Be}$ ratio using absolute dipole moment values 
(Carcaillet et al., 2004b) provided a relationship in the form : $\mathrm{P}=\mathrm{c} \cdot \mathrm{M}^{-\mathrm{x}}$ [where $\mathrm{P}$ is the cosmogenic nuclide production at time $\mathrm{t}, \mathrm{M}$ is the magnetic moment at a time $\mathrm{t}, \mathrm{c}$ is a constant, and $\mathrm{x}$ is a natural number], in remarkable agreement with relations established by Elsasser et al. (1956) and Lal $(1988,1992)$.

Another proxy of the sediment flux, the excess of Thorium 230 $\left({ }^{230} \mathrm{Th}_{\mathrm{xs}}\right)$ has been used on sediment sequences from the South Atlantic (last $300 \mathrm{ka}$ on ODP leg 177, site 1089; Christl et al., 2007) and from the North Atlantic (an interval near 180-220 ka BP at ODP sites 983 and 1063; Knudsen et al., 2008).

Low ${ }^{10} \mathrm{Be} /{ }^{9} \mathrm{Be}$ ratios accompany high and medium RPI values, and conversely, all peaks of the authigenic ${ }^{10} \mathrm{Be} /{ }^{9} \mathrm{Be}$ ratio occur at the same time (depth) as RPI drops. This proves that over these intervals of the Brunhes and late Matuyama epochs, the RPI lows linked with excursions and reversals were global and provoked cosmogenic nuclide enhancements. We thus feel allowed to call them geomagnetic dipole lows or GDL.

In the Portuguese margin sequence the series of RPI lows and cosmogenic nuclide production enhancements recorded for the last $300 \mathrm{ka}$ (Fig. 1) are directly linked to paleomagnetic excursions.

- The Laschamp excursion is recorded as large amplitude directional swings occurring in a major RPI low (Labeled "a") located at $1420-1450 \mathrm{~cm}$. The corresponding ${ }^{10} \mathrm{Be}$ overproduction
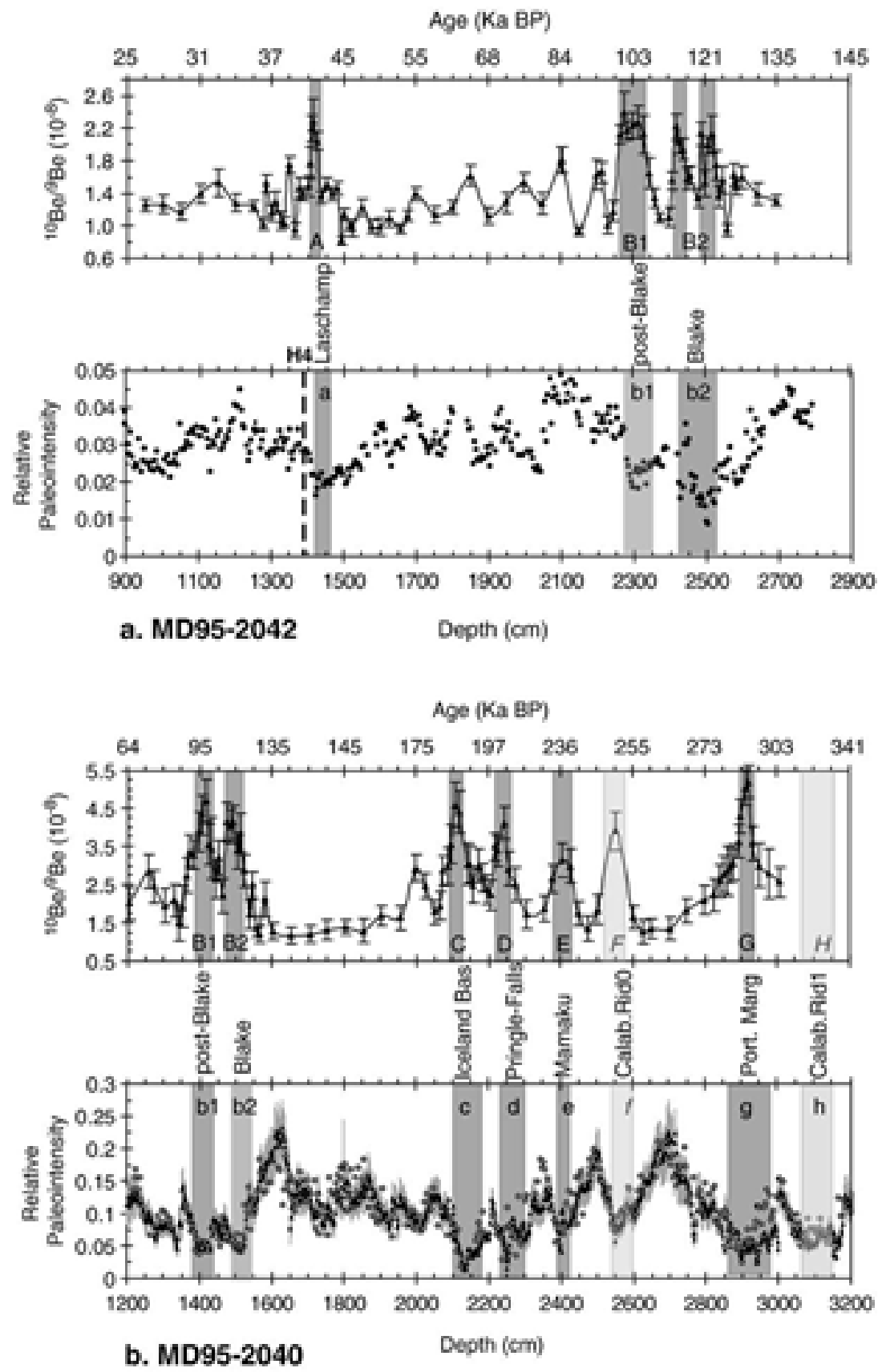

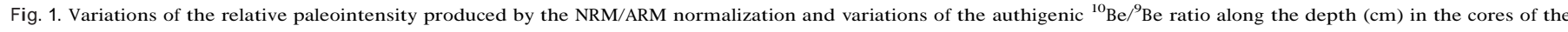

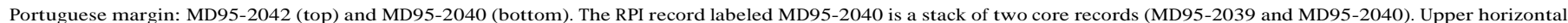

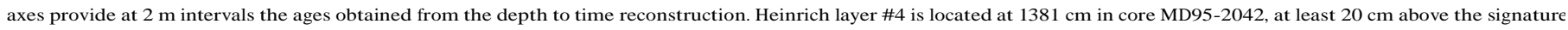

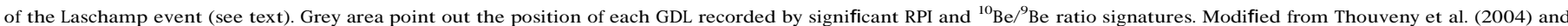
Carcaillet et al. (2004a,b). The cosmogenic response to GDL "h" was recently revealed (labeled here H) (Jouve, Bourlès, Thouveny unpublished Master thesis). 
(labeled A) is located at $1400-1425 \mathrm{~cm}$ which suggests a lock-in depth of the magnetization of 20-25 cm. These expressions of the dipole collapse are recorded at the age of 41-42 ka BP (using calibrated ages of Bard et al., 2004). They lie 20-30 cm beneath the IRD layer of Heinrich Event \#4, itself independently dated at $39.4 \pm 0.95 \mathrm{ka}$ BP (Thouveny et al., 2000). This robust stratigraphic constraint on the age of the Laschamp perfectly agrees with its chronological position in the GLOPIS record (Laj et al., 2004), as well as with the ages $\left[{ }^{40} \mathrm{Ar} /{ }^{39} \mathrm{Ar}\right.$ age $=39.2 \pm 2.5 \mathrm{ka} \mathrm{BP}(1 \sigma) ; \mathrm{K} / \mathrm{Ar}$ age $=41.4 \pm 1 \mathrm{ka} \mathrm{BP}(1 \sigma)]$ obtained on the Laschamp and Olby flows (Guillou et al. (2004). It thus implies that the collection of K/Ar age (average age $=37 \pm 0.7 \mathrm{ka} \mathrm{BP}$ ) recently obtained by Plenier et al. (2007) may be biased by younger excursional lava flows.

- In the 60-80 ka BP interval the RPI record shows 3 minor drops, but the relatively low resolution of the cosmogenic isotope record does not reveal significant change. Yet, RPI low were reported at this time in lake records of le Bouchet (Thouveny et al., 1993) and Baikal (Peck et al., 1996; Demory et al., 2005) as well as in marine records (Guyodo and Valet, 1999; Laj et al., 2004), and an excursion was signaled in cores of the Norwegian sea (Nowaczyk and Frederichs, 1999).

- Between 90 and $125 \mathrm{ka} \mathrm{BP}$ a long lasting RPI low is divided into two sub-units (b1 and b2) centered at 95-100 ka BP and 115$120 \mathrm{ka}$ BP respectively. The oldest one accompanied by a double inclination anomaly and a declination swing has been correlated to the Blake event (e.g. Creer et al., 1980; Tric et al., 1991) dated between 114 and 120 ka BP (e.g. Fang et al., 1997). The same succession was signaled by Thouveny et al. (1990) in the Lac du Bouchet record: an excursion at $95 \mathrm{ka}$ BP followed a nearly complete reverse to normal transition occurring at $115 \mathrm{ka} B P$ attributed to the Blake event. The youngest excursion reported in the Portuguese margin record was provisionally called here the "post-Blake" excursion. The major GDL "containing" the two excursions lasts 30 to $35 \mathrm{ka}$ and is signed in the two studied cores (Figs. 1 and 3) by two (in MD95-2040) or three (in MD95-
2042) successive episodes of cosmogenic nuclide overproduction ("B1" and "B2").

- Between 185 and 198 ka BP a deep RPI low (c) accompanies large inclination and declination swings. A significant cosmogenic nuclide production enhancement (C) occurs at $190 \mathrm{ka}$ BP. This expresses the "Icelandic basin event" a short full reversal defined on ODP cores 983 and 984 (Channell, 1999), and confirmed in the Lake Baikal sediments (Oda et al., 2002; Demory et al., 2005).

- Between 200 and $215 \mathrm{ka}$ BP, a RPI low (d) and a cosmogenic nuclide production enhancement (D) correlate with the Pringle Falls excursion dated at $218 \pm 10 \mathrm{ka} \mathrm{BP}$ by ${ }^{40} \mathrm{Ar} /{ }^{39} \mathrm{Ar}$ on a tephra of this locality (Herrero-Bervera et al., 1994).

- Centred at $240 \mathrm{ka} \mathrm{BP,} \mathrm{a} \mathrm{marked} \mathrm{RPI} \mathrm{low} \mathrm{(e)} \mathrm{and} \mathrm{a} \mathrm{minor}$ cosmogenic nuclide production enhancement (E) occur at $\sim 236 \mathrm{ka}$ BP. This agrees with the age of $230 \pm 12$ ka BP obtained on excursional lavas at Mamaku (New Zealand; Shane et al., 1994), until now supposed to have recorded the Pringle falls excursion (e.g. McWilliams, 2001). A small amplitude RPI drop (f), validated by one single cosmogenic nuclide enhancement (F) falls at 250$255 \mathrm{ka} \mathrm{BP}$, time of the Calabrian ridge 0 excursion (Mediterranean core KC-01B, Langereis et al., 2000) and Fram strait excursion (Nowaczyk and Frederichs, 1999).

- At 290 ka BP the deep RPI low (g) associated with anomalous directions defining the "Portuguese margin excursion" is accompanied by a sharp cosmogenic nuclide production enhancement $(G)$. - At 315-320 ka BP, with the deep RPI low (h) a significant ${ }^{10} \mathrm{Be}$ enhancement labeled here " $\mathrm{H}$ " was recently revealed (Jouve, Bourlès, Thouveny, unpublished results).

The cosmogenic nuclide record of the cores of the Portuguese margin is now under completion using the Accelerator mass spectrometer "ASTER" installed at Cerege in 2006.

For the 300-800 ka BP time interval the global stacked record Sint800 (Guyodo and Valet, 1999) can be compared with the magnetization record of the South-East Pacific deep sea floor (DSF) measured with a deep-tow magnetometer (Gee et al., 2000). Such record derives

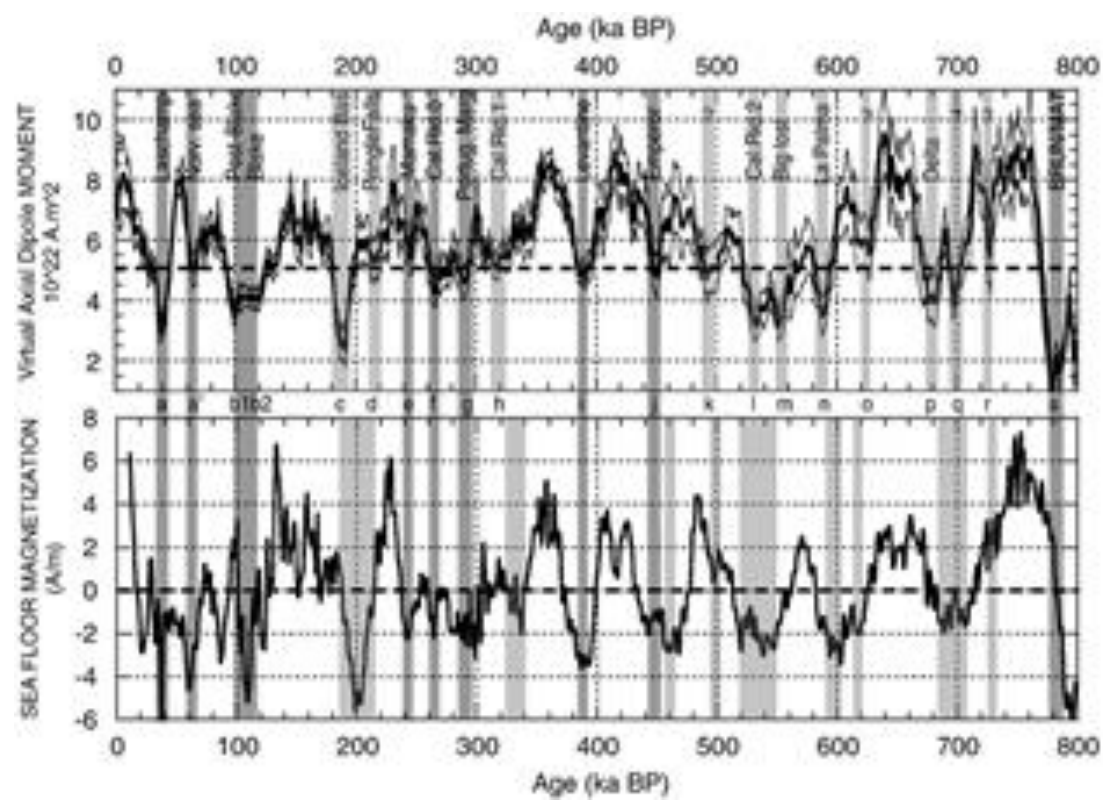

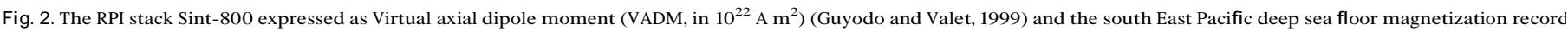

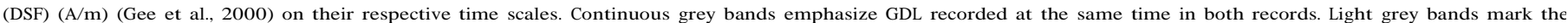

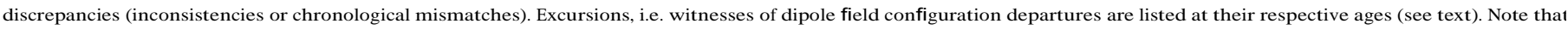

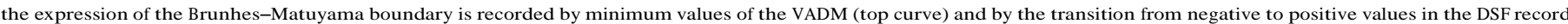
(bottom curve). 


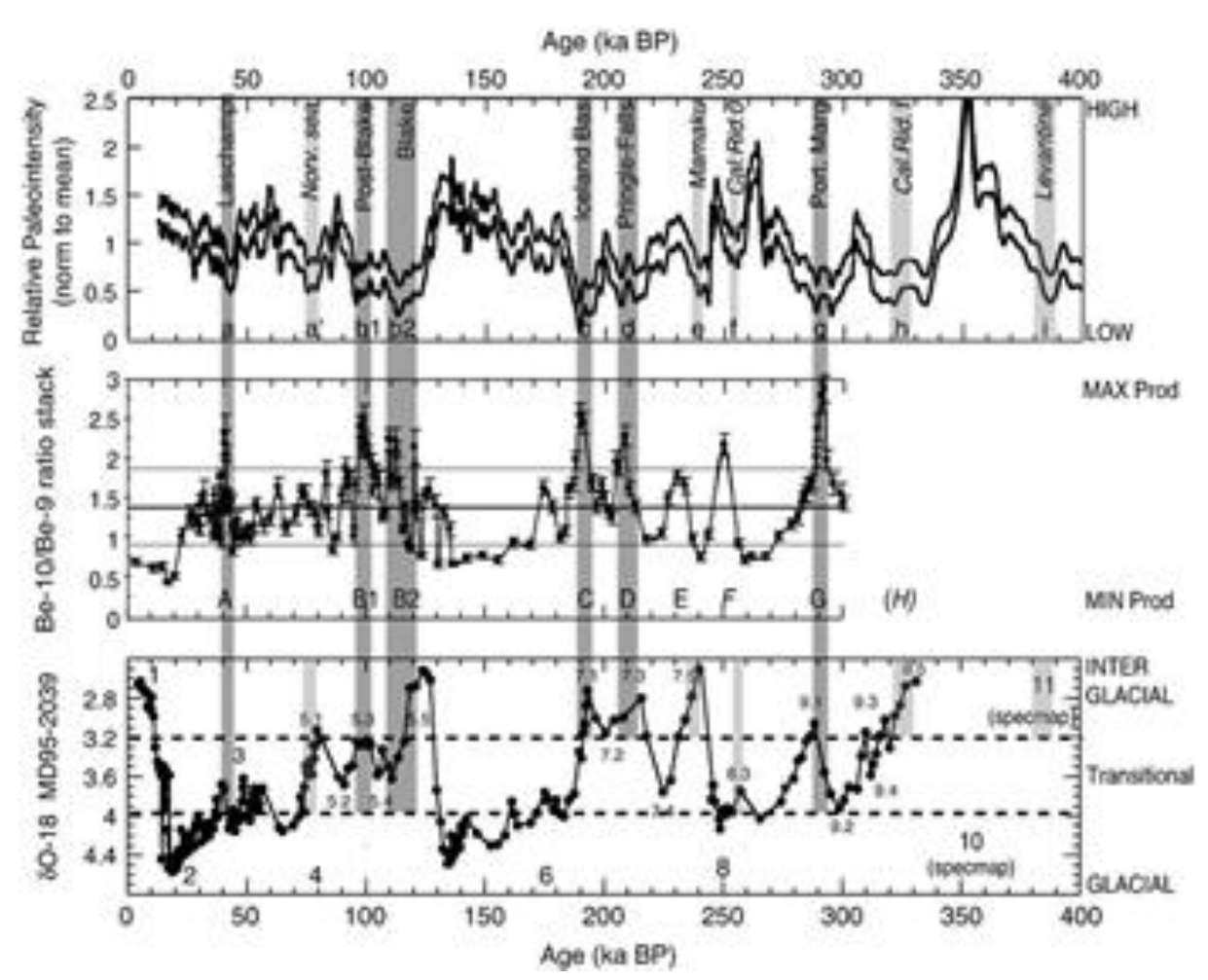

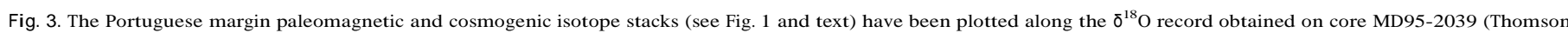

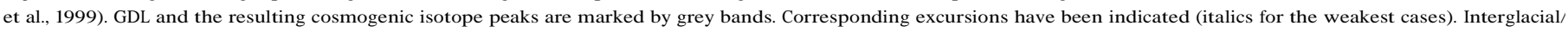

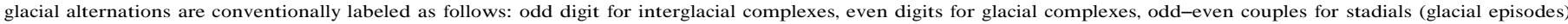

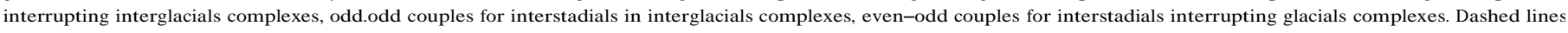

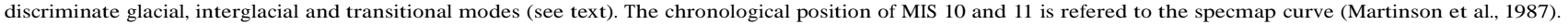

from radically different concepts and methods, both for the variable measured (a magnetic field) and for the spatial variation (temporal variability). The variable depends on the thermo-remanent magnetization acquired by underlying crust at the time of its formation. Assuming a reasonably constant ridge expansion rate, the time scale of the DSF record was derived by linear interpolation between 0 (present time) and $780 \mathrm{ka} \mathrm{BP}$, age of the B/M reversal (Gee et al., 2000). This proxy record should be interpreted as a regional record integrating contributions of the non-dipole field, however its advantage over sedimentary records lie in the total absence of paleoclimatic bias on the paleointensity proxy. As a matter of fact, neither the nature, nor the quantity of magnetic minerals of the oceanic crust, can be considered as being influenced by glacial/interglacial alternations.

The Sint-800 and DSF records on their respective time scales exhibit the same rhythms and amplitudes of deep lows, attributable to magnetizations acquired in a weak or even in a reverse field (Fig. 2). Since cross-correlation coefficients will drastically depend on wiggle matching, we found more efficient and convincing to analyze the series of GDL features on their own original time scales.

At $40 \mathrm{ka}$ the GDL a, associated with the Laschamp event appears as a relatively wide feature in the Sint-800, but as a very sharp reverse signal in the DSF record. Different structures are evidenced between 40 and 150 ka BP. A secondary feature labeled a' has been distinguished in both records at 60-65 ka BP, the age of the Norwegian sea excursion. GDL features b1 and b2 assignable to the post-Blake excursion and to the Blake event are recorded between 95 and $125 \mathrm{ka}$ BP in the Sint-800 and between 100 and $120 \mathrm{ka}$ BP in the DSF record. The GDL c, "Icelandic basin event" occurs at $190 \mathrm{ka}$ BP in Sint-800 and at $200 \mathrm{ka} \mathrm{BP}$ in the DSF record. At ca $218 \mathrm{ka} \mathrm{BP}$, the Sint- 800 contains a weak feature (d) related to the Pringle Falls excursion in the Portuguese margin record, which seems to be integrated in the descent from high intensities to the low c of the DSF record. The GDL e, linked with the Mamaku excursion, is weakly expressed at ca $240 \mathrm{ka}$ $\mathrm{BP}$ in both Sint- 800 and DSF records. Between 260 and $350 \mathrm{ka} \mathrm{BP}$, both records contain features of limited amplitude: GDL f (260 ka BP) linked to the Calabrian Ridge 0 (or Fram strait) excursion, GDL g (290 ka BP) linked to the Portuguese margin excursion, and GDL h (320 ka BP) linked to the Calabrian Ridge 1 excursion. At $390 \mathrm{ka}$ BP the GDL i is

Table 1

Geomagnetic dipole lows and related excursions of the last $400 \mathrm{ka}$ revealed in the Portuguese margin sequence are listed as a function of their age

\begin{tabular}{|c|c|c|c|c|}
\hline $\begin{array}{l}\text { RPI low } \\
\text { label }\end{array}$ & $\begin{array}{l}\text { Name of the } \\
\text { excursion } \\
\text { or event }\end{array}$ & $\begin{array}{l}{ }^{10} \mathrm{Be} /{ }^{9} \mathrm{Be} \\
\text { enhancement } \\
\text { label }\end{array}$ & $\begin{array}{l}\text { AGE }(k a B P) \\
\text { Portuguese } \\
\text { Margin record }\end{array}$ & $\begin{array}{l}\text { Occurrence of GDL vs } \\
\text { marine isotope stages in } \\
\text { the Portuguese Margin cores }\end{array}$ \\
\hline $\mathrm{a}$ & Laschamp & A & $41-43$ & $\begin{array}{l}\text { Interstadial } 3 \\
\text { (Dansg-Oeschg I.S.10) }\end{array}$ \\
\hline$a^{\prime}$ & Norwegian sea & Insignificant & 75 & End of interstadial 5.1 \\
\hline b1 & Post-Blake & B 1 & 100 & Interstadial 5.3 \\
\hline b2 & Blake & B2 & $110-120$ & End interglacial 5.5 \\
\hline $\mathrm{c}$ & $\begin{array}{l}\text { Icelandic } \\
\text { basin }\end{array}$ & $\mathrm{C}$ & 190 & End interglacial 7.1 \\
\hline d & Pringle Falls & $\mathrm{D}$ & $210235-$ & End interglacial 7.3 \\
\hline e & Mamaku & $\mathrm{E}$ & 240255 & End interglacial 7.5 \\
\hline f & CRO/Fram St & F single dat. & 290 & Interstadial 8.3. (glacial 8) \\
\hline $\mathrm{g}$ & $\begin{array}{l}\text { Portuguese } \\
\text { margin }\end{array}$ & $\mathrm{G}$ & & Interstadial 9.1 \\
\hline h & CR1 & H (unpub res.) & $315-320$ & $\begin{array}{l}\text { Interglacial } 9.5 \text { transition } \\
9.4 \text { (specmap) }\end{array}$ \\
\hline i & Levantine & Under study & $400-385$ & Interglacial 11 (specmap) \\
\hline
\end{tabular}

The paleoclimatic context of their occurrence is identified by the marine isotope stages labels (see text). Names in bold characters distinguish the excursions expressed by inclination and/or declination anomalies in the same cores. Bold numbers give the ages of cosmogenic nuclide enhancements. Italic data indicate cases to be completed. 
assignable to the Levantine excursion defined in cores V12-122 and RC9-181(Ryan, 1972) and core KC-01B record (Langereis et al., 2000).

Near $450 \mathrm{ka}$ BP, one single GDL (j) in the Sint 800 is expressed by a two-fold anomaly at 440-470 ka BP in the DSF. The "Emperor event" defined by one single reverse inclination datum in core V12-122 (Jamaica ridge; Ryan, 1972) was first loosely dated at $465 \pm 50 \mathrm{ka}$ BP on reversely magnetized lava flows from Idaho (Champion et al., 1981). Its re-dating on the same lavas at $565 \pm 14 \mathrm{ka} \mathrm{BP}$ led Champion et al. (1988) to redefine it as the "Big Lost event". Despite this ambiguity, we felt legitimate to keep the name "Emperor" for GDL $\mathrm{j}$ defined at $450 \mathrm{ka}$ BP.

At $500 \mathrm{ka} \mathrm{BP}$ a minor GDL (k) in the Sint-800 has no clear equivalent in the DSF record but can be related with another anomaly in the sea floor magnetic record of the Galapagos spreading centre, broadly dated at $490 \pm 50 \mathrm{ka}$ BP (Wilson and Hey, 1980).

Both records exhibit a two-fold GDL at $520 \mathrm{ka} \mathrm{BP}(1)$ and $555 \mathrm{ka} \mathrm{BP}$ (m) at the time of two known excursions: 1) Calabrian ridge 2 signaled at $\sim 515 \mathrm{ka}$ BP (Langereis et al., 2000) is related with anomalous directions and weak paleointensities recorded in lava flows of the Eifel (Germany) dated by ${ }^{40} \mathrm{Ar} /{ }^{39} \mathrm{Ar}$ at $528 \pm 16 \mathrm{ka} \mathrm{BP}$ (Singer pers. comm.). 2) Big Lost described in lava flows from Idaho dated at $565 \pm 14 \mathrm{ka} \mathrm{BP}$ (Champion et al., 1988) and re-dated at $558 \pm 20 \mathrm{ka}$ BP (Lanphere. 2000) also recorded by anomalous directions and weak paleointensities in lava flows of the Eifel dated by ${ }^{40} \mathrm{Ar} /{ }^{39} \mathrm{Ar}$ at $555 \pm 16 \mathrm{ka} \mathrm{BP}$ (Singer pers. comm.). The excursion and the GDL are both recorded at $\sim 540$ ka BP in ODP sites 983 and 984 (Channell et al., 2004).
At 590-600 ka BP a marked GDL (n) was related by Guyodo and Valet (1999) to an excursion recorded in lavas of La Palma Island

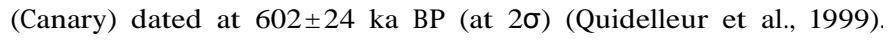
Another age of $580 \pm 8 \mathrm{ka}$ BP obtained from the same lavas by Singer et al. (2002) was first considered as identical with that $(558 \pm 20 \mathrm{ka} \mathrm{BP})$ obtained for the Big Lost excursion by Lanphere (2000). Recent dating of excursional lavas of the Eifel $(578 \pm 8 \mathrm{ka} \mathrm{BP})$ and of Tahiti $(579 \pm 6 \mathrm{ka}$ BP) (Singer pers. comm.), however tend to place the occurrence of the "La Palma excursion" at $\sim 580 \mathrm{ka} \mathrm{BP}$, in agreement with the age of GDL $\mathrm{n}$ at $590 \mathrm{ka}$ BP. Again, the excursion and the GDL are both recorded at $\sim 590 \mathrm{ka} \mathrm{BP}$ in ODP sites 983 and 984 (Channell et al., 2004).

At $620-630 \mathrm{ka}$ BP, both the Sint-800 and the DSF mark a first minimum before the La Palma excursion, this feature labeled o can be related to a full reversal recorded in a soil section in the Lishi loess sequence (Liu et al., 1988).

A two-fold feature, GDL $\mathrm{p}$ and $\mathrm{q}$, occurs in both records between 670 and $710 \mathrm{ka}$ BP. It can be related to a double inclination anomaly recorded in the Osaka bay sediments deposited in Marine isotope stage 17 (Biswas et al., 1999), and to a double inclination anomaly recorded in a low RPI phase in ODP sites 983 and 984 (Channell et al.. 2004). These authors correlated their excursion to the delta excursion. a low inclination feature, signaled by Creer et al. (1980), first dated at $620 \mathrm{ka} \mathrm{BP}$ and re-dated at $680 \mathrm{ka} \mathrm{BP}$ after revision of the age of the Brunhes/Matyuama boundary. Therefore from the two GDL, p and q, only $\mathrm{p}$, the younger ( $680 \mathrm{ka} \mathrm{BP}$ ) can be related to the Delta excursion.

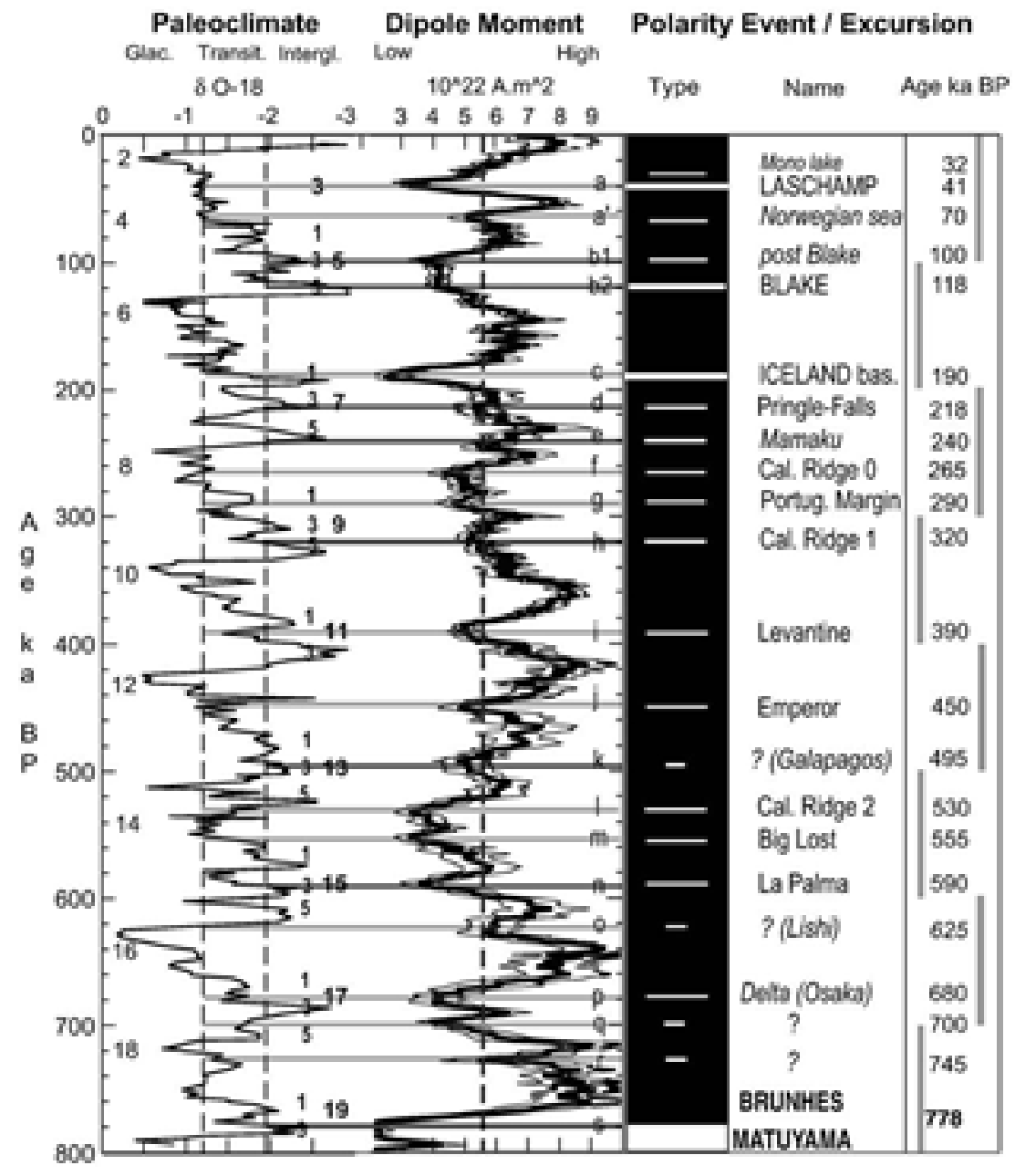

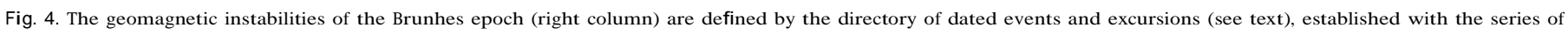

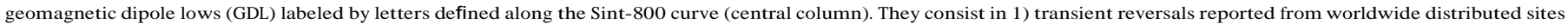

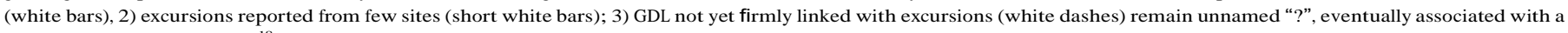

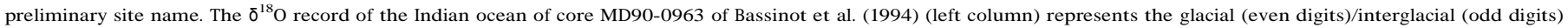
alternation. Dashed lines discriminate glacial, interglacial and transitional modes (see text). 
The other remains without name, although it was initially named as the Stage 17 excursion.

At 725-730 ka BP, a short drop in the Sint-800, r, occurs during the descent from high to low intensities in the DSF record. In the ODP site 983 and 984 records, a similar RPI low is recorded with large amplitude inclination variations just after the Brunhes/Matuyama transition here labeled "s". We emphasize that the expression of the Brunhes-Matuyama boundary is recorded by minimum values of the VADM (top curve) and by the transition from negative to positive values in the DSF record (bottom curve), thus justifying the apparent time shift of the two curves at this time.

This summary does not only completes previous compilations of "geomagnetic instabilities or reversal excursions" (e.g. Singer et al., 2002; Channell, 2006; Lund et al., 2006), it presents the strongest arguments for a robust interpretation of the relative paleointensity curves: i) cosmogenic isotope enhancements confirm the reality of RP] lows and allow interpreting them as GDL, ii) Most GDL are recognizable as anomalies of weak or reversed magnetization of the deep sea floor. This suggests that several GDL, other than Laschamp: Blake, and Icelandic basin, are expected to be accompanied by reverse directions in a growing number of high resolution paleomagnetic records. In several cases lasting episodes of low dipole moment are interrupted by short dipole moment increase. It is the case for the following twins: post-Blake/Blake, Iceland Basin/Pringle falls, Portuguese margin/Calabrian Ridge 1, Calabrian Ridge 2/Big Lost, and Delta/ unnamed. These structures mimic VADM variations across polarity subchrons (e.g. Jaramillo, Cobb Mountain and Olduvai). This may constitute a discriminating factor between GDL triggering excursions and GDL triggering short (aborted) reversals.

Finally these evaluations and comparisons suggest that the highest possible resolution is probably not yet reached by directional and RP] records, and is certainly hampered by stacking and averaging processes.

\section{Paleoclimatic or orbital constraints on geomagnetic dipole lows ?}

\subsection{A preferred occurrence in peculiar paleoclimatic contexts?}

The use of data sets measured on the same sediment cores allows a stratigraphic approach and avoids errors linked to transformation into time scales. Even though, offsets may be introduced by differential settling processes of biogenic and lithogenic particles and/or by significant and variable lock-in depth of the depositional remanent magnetization in sediments, still under debate (e.g. Roberts and Winklhofer, 2004 and Tauxe et al., 2006). Plotting RPI variations and authigenic ${ }^{10} \mathrm{Be} /{ }^{9} \mathrm{Be}$ ratio allows partly solving the latter problem. In Fig. 3 these geomagnetic intensity proxy records of the Portuguese margin cores are plotted besides the $\delta^{18} \mathrm{O}$ record of the sister core MD95-2039 (Thomson et al., 1999). Conventionally, in Fig. 3 and in Table 1, sub-stages are identified by a double labeling (e.g. odd-odd labels for interglacial sub-stages and odd-even labels for glacial substages, even-odd labels for "interstadials" interrupting a glacial, eveneven labels for glacial sub-stages in glacials. Note that MIS 8.5 is relabeled in MIS 9.1 in agreement with re-interpretations of $\delta^{18} \mathrm{O}$ records (Roucoux et al., 2006) and pollen records (Tzedakis, 2005).

Among the six GDL confirmed by significant cosmogenic enhancements, five (b1, b2, c, d and g) occurred during or at their terminations of interglacial marine isotope stages (MIS) 5.3, 5.5, 7.1, 7.3 and 9.1). The exception is GDL a, linked with the Laschamp excursion. It occurred during MIS 3 (30-55 ka BP), an "interstadial”, weakly expressed in $\delta^{18} \mathrm{O}$ records, but characterized by rapid fluctuations of the global (air and sea surface) temperatures (e.g. Shackleton et al., 2000; Bard et al., 2004; North GRIP members, 2004; Masson-Delmotte et al., 2006) and by a 60-85 $\mathrm{m}$ rise of the sea level (Chappell, 2002; Arz et al., 2007), implying a melting of $\sim 50 \%$ of the ice volume.

The five other cases of GDL (a', e, f, h and i) associated with excursions are linked to interstadials (MIS 5.1 and 8.3) or to interglacials (MIS 7.5, 9.5 and 11). Further studies are required to constrain the cosmogenic nuclide record. Finally, no GDL of the last $400 \mathrm{ka}$ can be linked to full glacial conditions, contrarily to former claims by Worm (1997).

In absence of longer term multiproxy records, testing such relationship over longer time series requires comparison of paleomagnetic and paleoclimatic series obtained from different cores, thus independently dated, which does not provide the same degree of confidence. In Fig. 4, the updated geomagnetic instability time scale (Section 2) section is shown besides the Sint-800 record. The planktonic $\delta^{18} \mathrm{O}$ record of core MD90-0963 (Bassinot et al., 1994) has been considered as the best paleoclimatic reference for its high resolution, and for its astronomical calibration anchored on the $\mathrm{B} / \mathrm{M}$

Table 2

Geomagnetic dipole lows and related excursions of the last $800 \mathrm{ka}$ (Sint-800) related with deep sea floor anomalies (text and Fig. 2) listed as a function of age

\begin{tabular}{lll}
\hline GDL label & Name of the excursion or event & AGE(ka BP) Sint-800 \\
\hline a & Mono & $34 \square$ (glopis) \\
a' & Laschamp & $41-43$ \\
b1 & Norwegian sea & 70 \\
b2 & Post-Blake & 100 \\
c & Blake & 118 \\
d & Icelandic basin & 190 \\
e & Pringle Falls & 215 \\
f & Mamaku & 240 \\
g & Calab R O/Fram strait & 260 \\
h & Portuguese margin & 290 \\
i & Calab. R 1 & 320 \\
j & Levantine & 390 \\
k & Emperor & 450 \\
l & Un-named Galapagos) & 495 \\
m & Calab. R 2 & 530 \\
$\mathrm{n}$ & Big Lost & 555 \\
o & La Palma & 590 \\
p & Un-named (Lishi) & 625 \\
q & Delta or Osaka Bay & 680 \\
r & Un-named (q) & 700 \\
s & Un-named (r) & 745 \\
\hline
\end{tabular}

Occurrence of GDL - excursions vs
paleoclimate in MD90-0963
Interstadial 3
i.s. \#10 of Greenland ice records
End interstadial 5.1
Interstadial 5.3
End interglacial 5.5
End interglacial 7.1
Interglacial 7.3
Interglacial 7.5
Interstadial 8.3 . (glacial 8)
Interstadial 9.1
End interglacial 9.5
Stadial 11.2. (interglacial 11)
Interstadial 12.3. (glacial 12)
Interglacial 13.3
Transition glacial 14-interglacial 13.5
Transition interglacial 15.1-glacial 14
Interglacial 15.3
Transition glacial 16-interglacial 15.5 .
End interglacial 17.3 (stadial17.2)
Stadial 17.4
Interstadial 18.3 (glacial 18)
End interglacial 19.3 (transitional 19.2

Obliquity trend at this age

Minimum

Inflection descent

Minimum

Minimum

Minimum

Maximum

Inflection descent

Minimum

Maximum

Minimum

Minimum

Inflection descent

Maximum

Maximum

Minimum

Maximum

Maximum

Minimum

Maximum

Minimum

Inflection descent

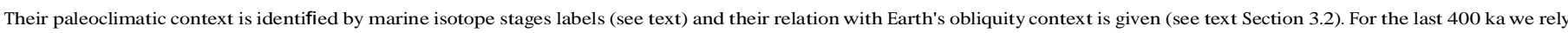

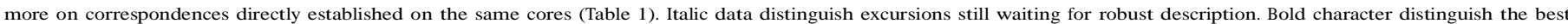
documented and dated excursion or reversal linked with GDL. 
boundary. In order to better analyze the correspondence, we discriminated three paleoclimatic modes in the $\delta^{18} \mathrm{O}$ record: the glacial (even labels) and interglacial (odd labels) modes include the most reduced features glacial MIS 14 and interglacial MIS 19. Intermediate $\delta^{18} \mathrm{O}$ values correspond to a transitional mode between interglacial and glacial.

The comparison presented in Fig. 4 and summarized in Table 2 confirms the case analyzed for the last $400 \mathrm{ka}$ along the Portuguese margin record (Fig. 3) and completes the observation for the interval 400-800 ka BP. Over the 21 described GDL, 17 are tightly related to documented and labeled excursions), 8 cases occurred in full interglacial conditions and 13 cases occurred in a "transitional" state. The latter consist in four different types: 1) marked interstadials (5 cases), 2) Interglacial to mid-glacial transition (3 cases), 3) glacialinterglacial transitions (deglaciations) (3 cases), 4) significant recession of the glacial climate such as MIS 3 and MIS 8.3.

The comparison of paleomagnetic and cosmogenic isotopes records (Carcaillet et al., 2003) with the $\delta^{18} \mathrm{O}$ record (de GaridelThoron et al., 2005) of core MD97-2140 (West-Pacific) (Fig. 5) further supports these observations: GDLs at $590 \mathrm{ka}$ and $690 \mathrm{ka} \mathrm{BP}$, attributable to the La Palma and Delta excursions fall in interglacial stages 15 and 17 respectively. The Brunhes/Matuyama reversal accompanied by a strong dipole field collapse documented in the RPI record and in the cosmogenic isotope record occurred at the end of isotope stage 19. This was confirmed by the increase of the cosmogenic isotope flux recorded in Antarctic ices deposited during the end of stage 19 in the EPICA dome C core (Raisbeck et al., 2006). Prior the mid-pleistocene transition (at $\sim 900 \mathrm{ka} \mathrm{BP}$ ) weak amplitudes and short periods $(\mathrm{T}=41 \mathrm{ka})$ of the paleoclimatic variations preclude such interpretation.

Paleomagnetic records of RPI and directions, cosmogenic nuclide signatures and $\delta^{18} \mathrm{O}$ stratigraphies will benefit from the highest possible signal/noise ratio in sedimentary sequences collected in high sedimentation rate area. Such future research will enable testing the statistical significance of such links. The present status of our analysis is however sufficient to definitely reject the link claimed by Worm (1997) between excursions and glaciations. If the occurrence of GDL in interglacial or transitional paleoclimatic context is confirmed as a robust and non-fortuitous characteristic, it will imply orbital influences on the geomagnetic field intensity.

\subsection{Do orbital influences appear in the GDL time series?}

The hypothesis of indirect orbital influence via the role of ice sheets can be evoked. The last $900 \mathrm{ka}$, and more particularly the last $400 \mathrm{ka}$, were characterized by the presence of giant ice sheets at high and mid latitudes of the Northern hemisphere that abruptly melt when the summer insolation at $65^{\circ} \mathrm{N}$ reached maximum values (e.g. Berger and Loutre, 1991). This occurred at obliquity maxima (i.e. each $41 \mathrm{ka}$ ) (e.g. Masson-Delmotte et al., 2006 and references therein), and was amplified at precession maxima [i.e. N.H. summer occurring at the perihelion $(\omega=\pi / 2)$ when the Earth-Sun distance is minimum (i.e. at maximum eccentricity)]. This is why the spectrum of glacial/ interglacial alternations contains these orbital periods, although the dominance of the $100 \mathrm{ka}$ period and the absence of the $400 \mathrm{ka}$ period are not fully understood.

Relations observed for the historical times between variations of the geomagnetic dipole moment and variations of the length of day (i.e. Earth's rotation speed) (e.g. Jin, 1992) suggest that on longer time scale such coupling may have existed. Now at the scale of glacialinterglacial times, Earth's angular speed changes may have resulted from several mechanisms. First, latitudinal redistributions of water masses between ice caps and the ocean (although $130 \mathrm{~m}$ of sea level variation only concern a water mass of $7 \cdot 10^{-6}$ of the Earth's mass). Second, a synergic contribution from tidal frictions is suggested by Lourens et al. (2001) who showed that over glacial times, the sea level drops, due to ice caps water storage, resulted in a weaker tidal dissipation and thus a higher Earth's angular speed.

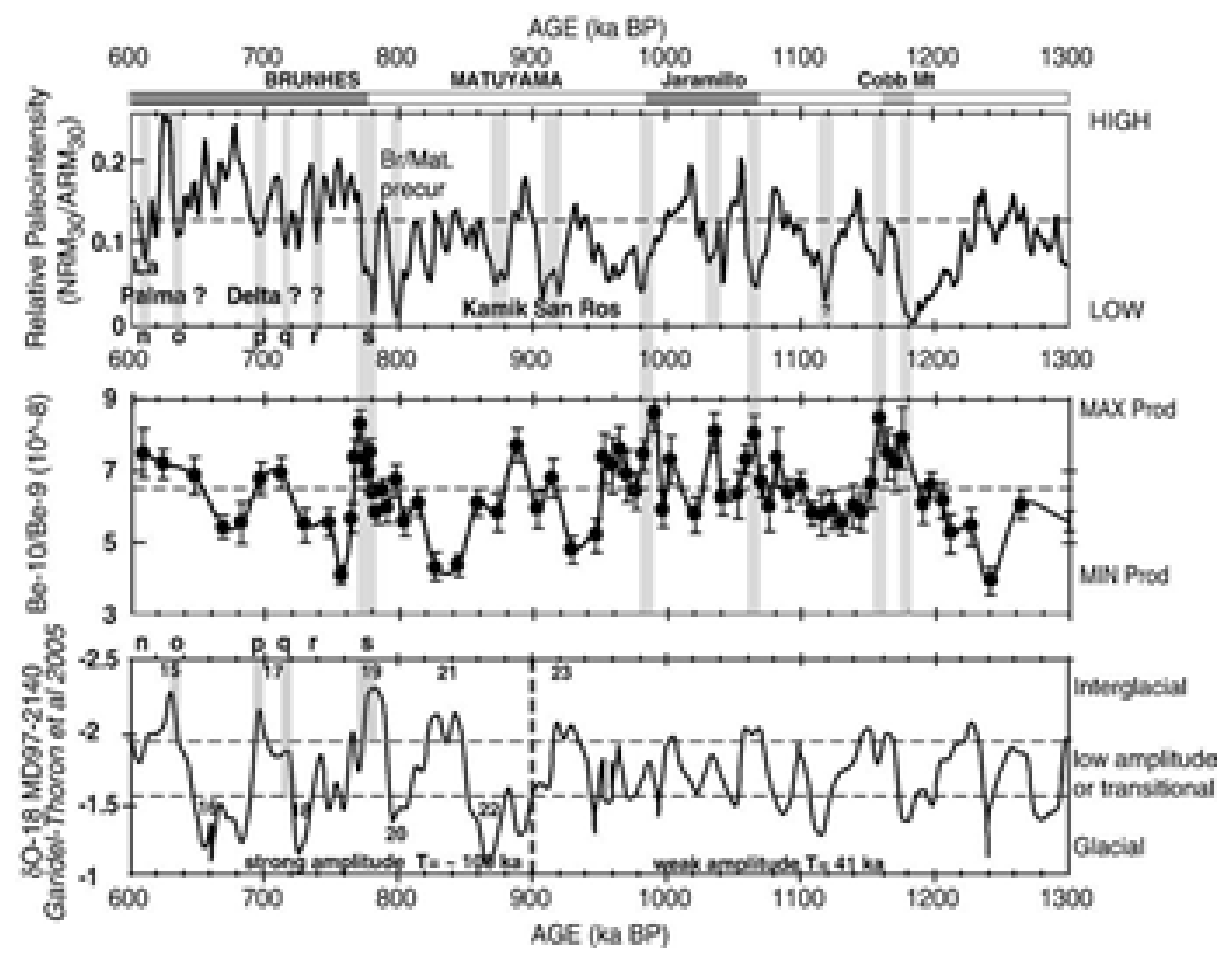

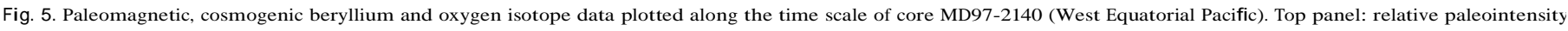

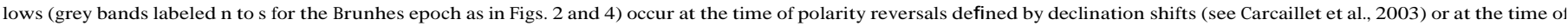

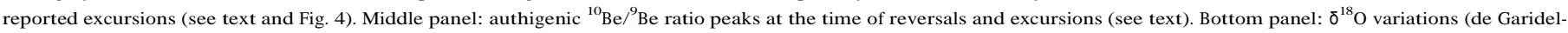

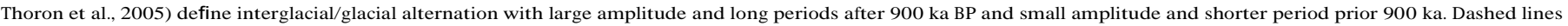
discriminate glacial, interglacial and transitional modes (see text). Grey bands underline RPI lows falling in interglacial stages 15 , 17 and 19. 
A direct influence of orbital parameters, namely astronomical precession (cf Introduction) represents however a more realistic, and common, forcing on the geomagnetic and paleoclimatic variations. Therefore, orbital influences on the GDL records have been investigated using two strategies.

1) Plotting VADM variations besides variations of orbital parameters (data from Berger and Loutre, 1991) (Fig. 6) demonstrates that there is no particular relationship between GDL and eccentricity or equinoxial precession contexts. By contrast, Fig. 6 and Table 2 reveal that from the 20 reported GDL, 13 (a, a', b, c, e, f, h, i, j, m, p, $r$, s) fall at obliquity minima, or at the inflection point of the descent from high obliquity (a, e, j, s). This namely concerns the four best documented and dated ( $a, b, c$ and s), linked with reversed events (Laschamp, Blake, Icelandic basin) and with the $\mathrm{B} / \mathrm{M}$ reversal. Other cases $(\mathrm{d}, \mathrm{g}, \mathrm{k}, \mathrm{l}, \mathrm{n}, \mathrm{o}$, and $\mathrm{q}$ ) fall near, or at, obliquity maxima: $\mathrm{d}$, confirmed by cosmogenic enhancement, is associated with the Pringle Falls excursion dated at $218 \mathrm{ka}$ BP, with an error bar of \pm 10 ka allowing some tolerance. Features $\mathrm{k}$ and $\mathrm{o}$, are relatively minor wiggles in the Sint-800 and the DSF and are not yet firmly related with well-dated excursions. Features 1 and $\mathrm{n}$, are shifted by $+10 \mathrm{ka}$ and $-10 \mathrm{ka}$ respectively in the DSF record, where they appear at $520 \mathrm{ka} \mathrm{BP} \mathrm{(1)} \mathrm{and} 600 \mathrm{ka} \mathrm{BP} \mathrm{(n),} \mathrm{related}$ with obliquity minima. Finally only GDL g (related to the Portuguese margin excursion) and $\mathrm{q}$ (yet related to no excursion) remain linked with obliquity maxima; they are interestingly coupled with GDL 1 and $\mathrm{p}$, under the form of twinned GDL.

Finally among the $20 \mathrm{GDL}$ discussed, 13 cases against 2 support the Fuller's (2006) conclusions of a link between geomagnetic polarity instabilities and low or decreasing obliquity (cf Introduction). It is interesting to add that, if they were linked to decreasing or low obliquity, GDL arithmetically occurred 10 to 20 ka after obliquity maxima. Since the latter have triggered deglaciations (MassonDelmotte et al., 2006), the coincidence of many of the GDL with the end of interglacial stages appears as a logical consequence of a link to low obliquity (Table 2).

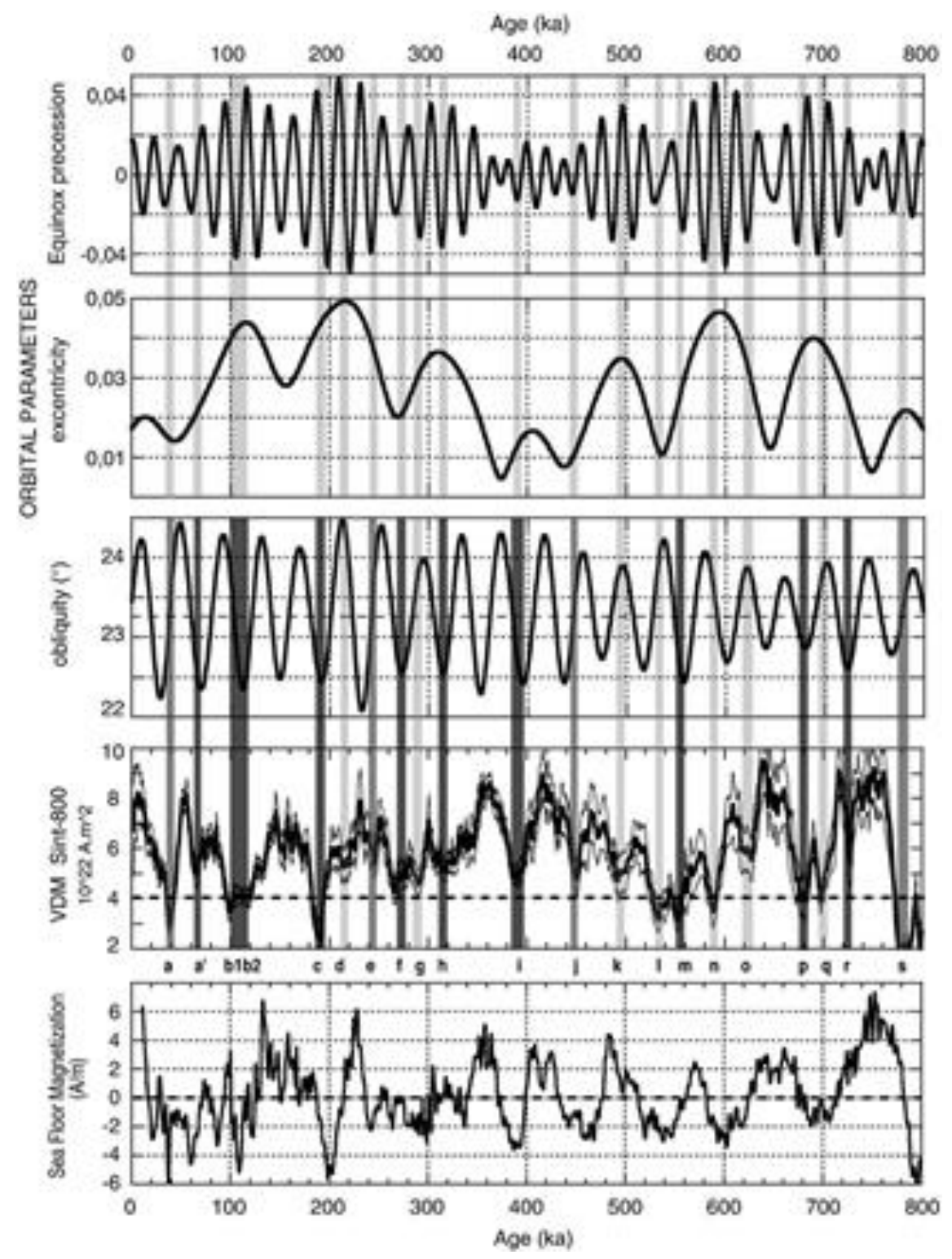

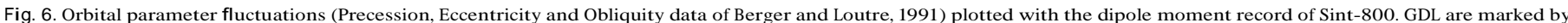

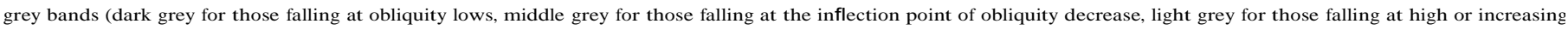

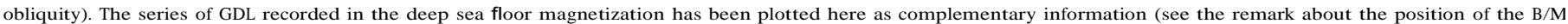
boundary in legend of Fig. 2). 
2) Investigations of power spectra of the dipole moment variations were performed using a complex continuous wavelet transform (CCWT) method (Saracco et al. submitted to Geophyscial Journal International) developed for acoustic physics, based on the extraction of a ridge from the phase of the CCWT, allowed under particular conditions of the wavelet with respect to the signal (Saracco et al., 1991; Guillemain et al., 1991; Delprat et al., 1992; Saracco, 1994; Saracco et al., 1990). The first step in working with a complex analyzing wavelet is to obtain a complex wavelet transform. Two complementary pieces of information are obtained: the modulus and the phase of the transform. From the phase of the CCWT are extracted the ridges corresponding to the frequency modulation laws of the signal, and from the modulus values along these ridges are extracted the amplitude modulation laws. The second interest to work with a complex analyzing wavelet is that the phase is defined even if the signal energy (or modulus) is low, which allows extracting spectral lines. This method therefore provides robust results on noisy signals, and a quantification of the power of signals at a given frequency.

The results obtained on RPI and Beryllium stacks for the last $300 \mathrm{ka}$ ( Fig. 7), on the Sint-800 and on the deep sea floor record for the last 800 ka (Fig. 8) are interpreted in Table A1 in the Appendix. These time series all present maximum modulus around periods shifting between $40 \mathrm{ka}$ and $125 \mathrm{ka}$. The 40-50 ka period mostly expressed in the long records might be an obliquity period biased by chronological
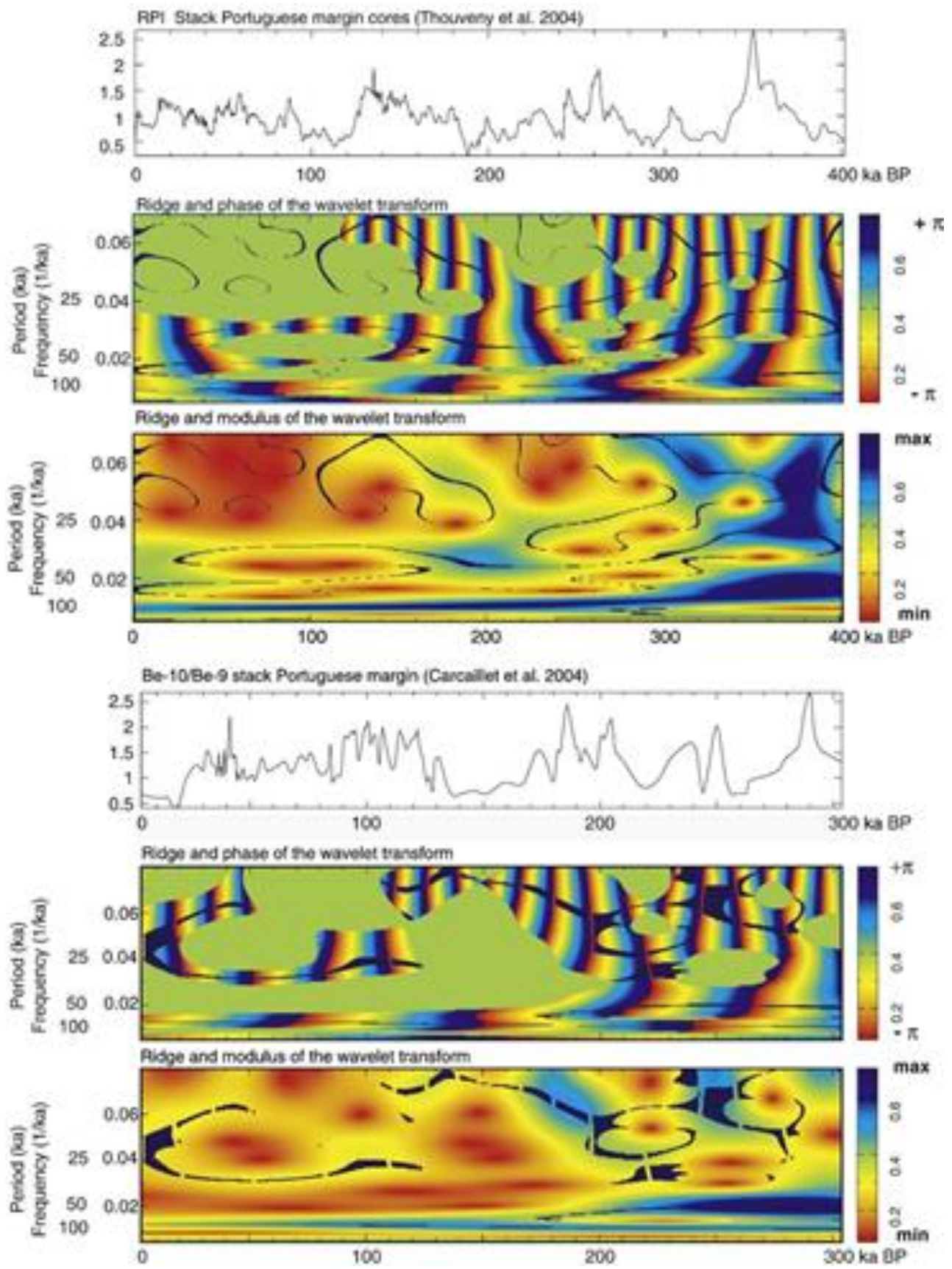

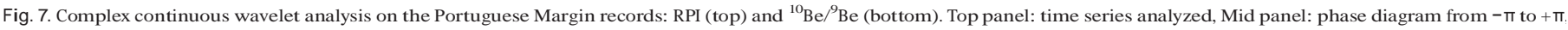

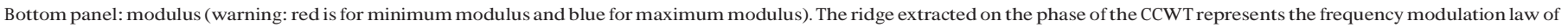
the signal. Frequencies as well as periods are indicated. 
imperfections. The range 91-125 ka encompassing characteristic periods of the eccentricity is well expressed in most time windows. The intermediate range (67-83 ka) expressed in several time windows of the long records might result from mixtures of, or shifts between. the two framing period ranges.

Using the same CCWT analysis, we checked the relationship between GDL and interglacial stages by comparing the phase diagrams of Sint-800 and MD90-0963 $\delta^{18} \mathrm{O}$ record (Fig. 9). The fact that the two phase diagrams are similar for the $100 \mathrm{ka}$ period supports the hypothesis of a common forcing. Over the last $400 \mathrm{ka}$, the paleocli- matic signal seems to lead the dipole signal by 10 to $20 \mathrm{ka}$, which is fully compatible with the phase shift of $\sim 18$ ka deduced from crosscoherence and phase analyses on the Portuguese margin records (Thouveny et al., 2004, Fig. 13). This reinforces the observation that GDL occurred during or at the end of interglacial stages, deduced from the analysis of Figs. 3 and 4.

Since it is now accepted that precession can in principle supply the geodynamo with abundant power (e.g. Roberts and Wu, 2005; cf Introduction) the presence of near orbital periods in the geomagnetic moment records, revealed by our - as well as other's - spectral

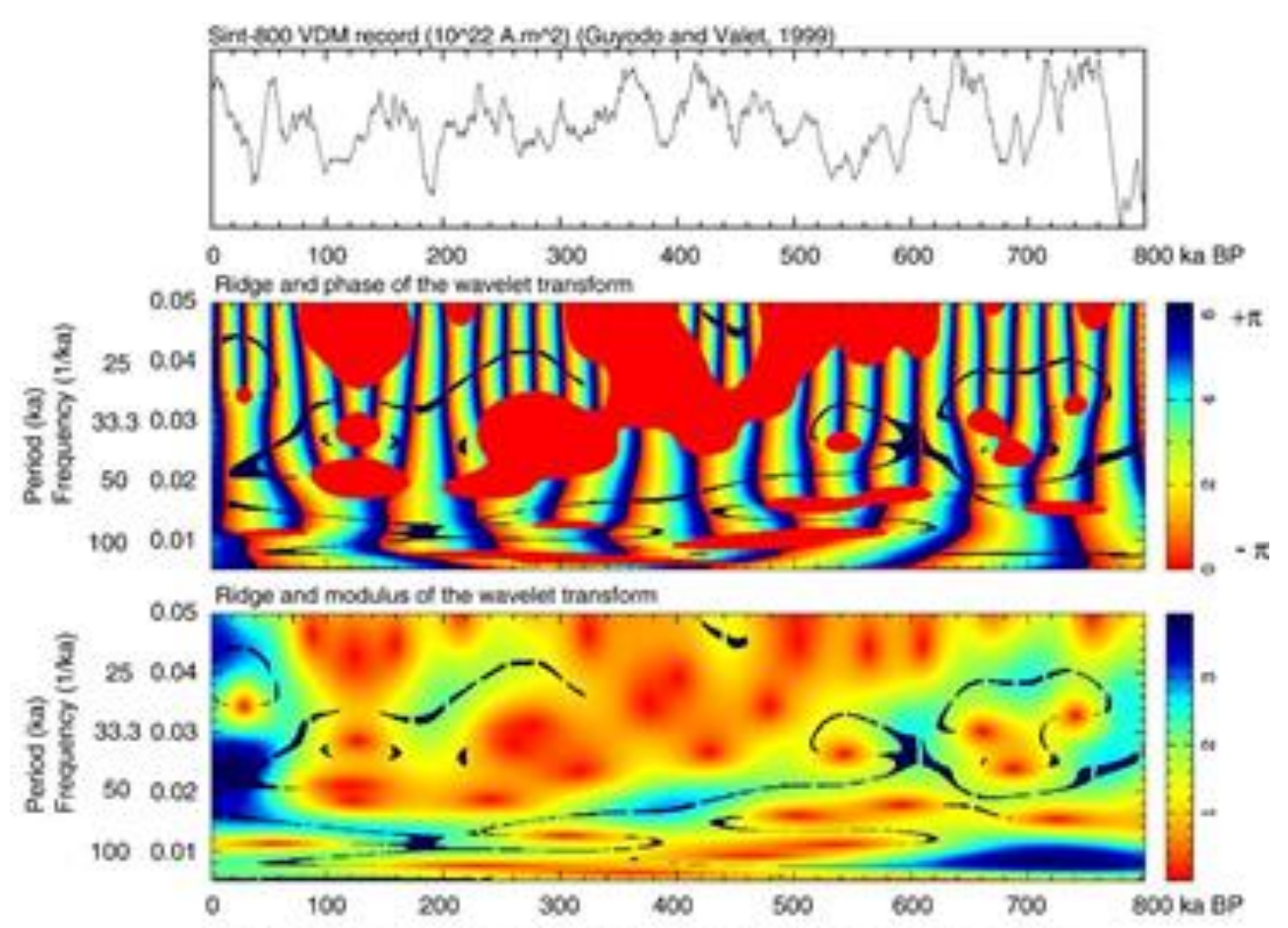

DEEP SEA FLOOR MACNETRATION (ANm) (S.E. PACIFIC RIDGE (Gee et al 2000)
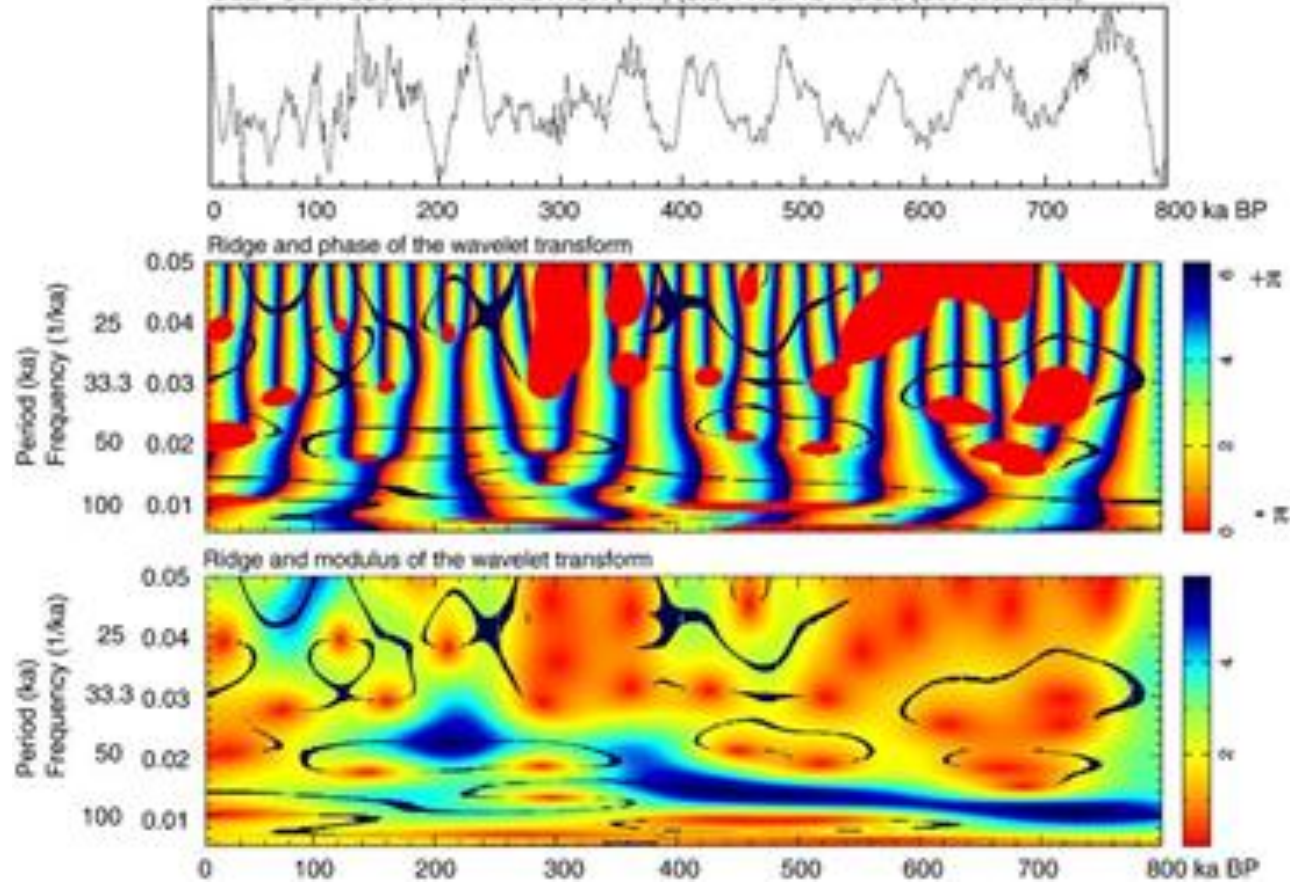

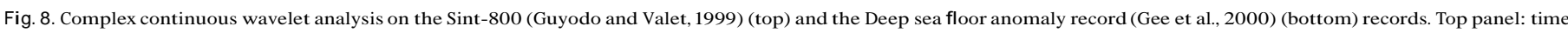

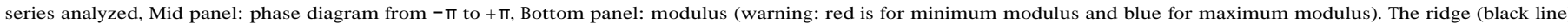
extracted on the phase of the CCWT represents the frequency modulation law of the signal. Frequencies as well as periods are indicated. 


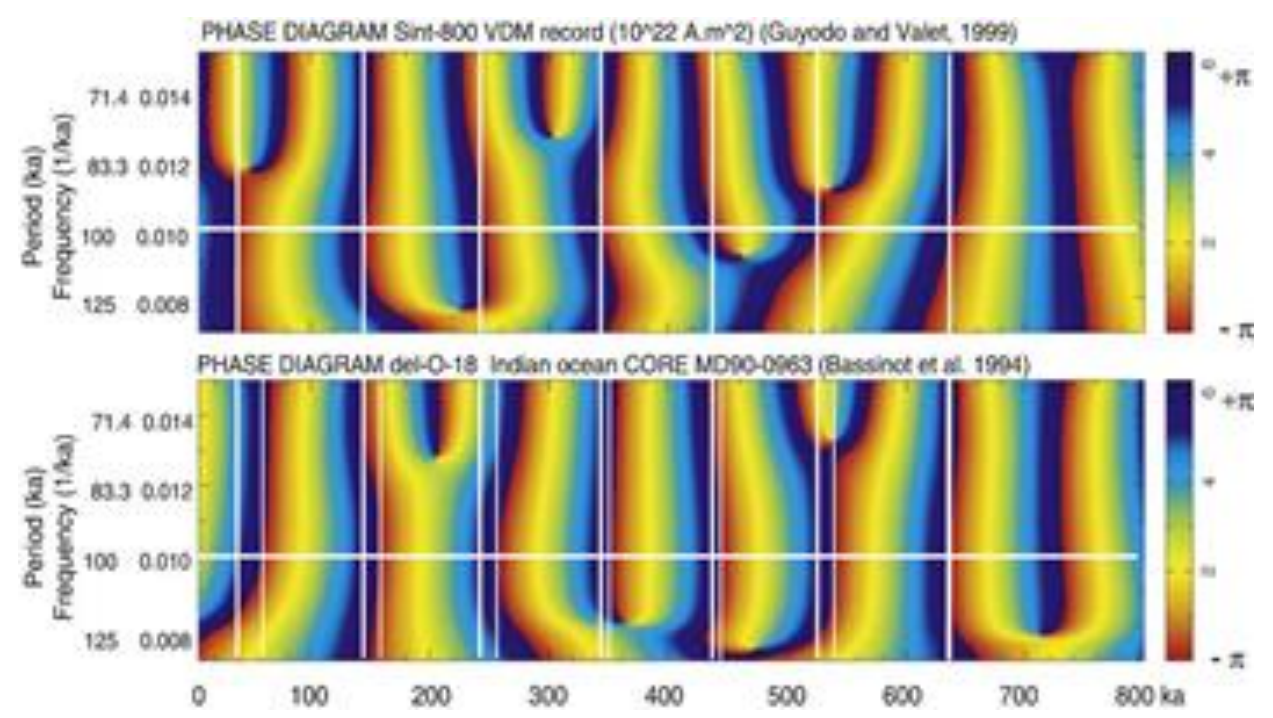

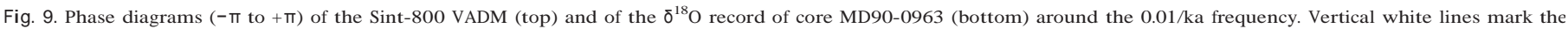

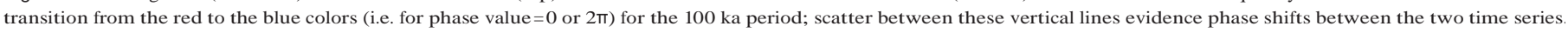
(For interpretation of the references to color in this figure legend, the reader is referred to the web version of this article.)

analyses implies that the rejection of hypotheses of mechanical disturbances of the geodynamo by rotational and/or precessional motion is at least premature.

\section{Conclusion and perspectives}

All available records of the Earth's magnetic field activity over the Brunhes epoch [1) paleodirections and paleointensity reconstructed from sediment sequences, 2) anomalies carried by the thermoremanent magnetization of the deep sea floor basalts, and 3) variations of the production of cosmogenic isotopes] document a series of geomagnetic dipole lows (GDL) that triggered instabilities of the polarity, excursions or events. These features of undisputable geomagnetic origin, present intriguing relationships with paleoclimatic and/or orbital time series: i) many of them occurred preferentially during or at the end of interglacial or interstadial episodes, ii) in agreement with Fuller's (2006) observations, the best dated and best characterized as full reversals (Laschamp, Blake, Icelandic basin and the Brunhe-Matuyama reversal) occurred when the Earth's obliquity was low or decreasing, iii) major periods slide between 40 and $125 \mathrm{ka}$.

The relationship of GDL with the end of interglacial stages and with low obliquity, if confirmed will constitute a logical consequence of the direct orbital forcing on both the geomagnetic field and the paleoclimate variations.

Altogether, the results of this study (and hopefully future studies) have crucial implications for the knowledge of the future evolution of the Earth's environment.

1) They imply that the next dipole field collapse, triggering the next excursion or reversal (e.g. Hulot et al., 2002; Constable and Korte, 2006), should start prior the end of the present interglacial stage. Will this interglacial stage last only few more millennia (like MIS 5.5)? Or will it last much longer, as its astronomical equivalent MIS 11 (Berger and Loutre, 2002)?

2) Throughout the last $800 \mathrm{ka}$, the dipole moment collapses have triggered huge and lasting cosmic rays fluxes at the Earth's surface. Effects of the heliomagnetic or geomagnetic screenings of such cosmic rays flux on the Earth's climate (e.g. Svensmark and FriisChristensen, 1997; Courtillot et al., 2007, 2008 and comments by Bard and Delaygue, 2008) should be expressed by significant paleoclimatic variations. The fact that these cosmic ray fluxes occurred at various phases of interglacial context (although mostly near their end) suggests that at this time scale their climatic effects, if any, are not legible.

\section{Acknowledgments}

Our studies were funded by the INSU programs "Intérieur de la Terre" from 2000 to 2003, "DyETi (Dynamique de la Terre Interne" from 2005 to 2006) and SEDIT since 2007. Other contributions from the french "Agence Nationale de la Recherche" are acknowledged through the SESAME (ANR-05-BLANC-0101-01) and PICC (ANR-05BLAN-0312-01) programs. This paper benefited from the critical comments of 3 anonymous reviewers and of Jean-Pierre Valet.

This article is dedicated to Bill Goree who died on July 22nd 2007 and is behind the success of most paleomagnetic studies in the world since the late $80 \mathrm{~s}$

Supplementary data associated with this article can be found, in the online version, at doi:10.1016/j.epsl.2008.08.020.

Aldridge, K.D., Baker, R., 2003. Paleomagnetic intensity data: a window on the dynamics of Earth's fluid core? Phys. Earth Planet. Inter. 140, 91-100.

Aldridge, K.D., Seyed-Mahmoud, B., Henderson, G.A., van Wijngaarden, W., 1997. Elliptical instability of the Earth's fluid core. Phys. Earth Planet. Inter. 103, 365-394.

Arz, H.W., Lamy, F., Ganopolski, A., Nowaczyk, N., Pätzold, J., 2007. Dominant Northern Hemisphere climate control over millennial scale glacial sea level variability. Quat. Sci. Rev. 26, 312-321.

Bassinot, F., Labeyrie, L.D., Vincent, E., Quidelleur, X., Shackleton, N.J., Lancelot, Y., 1994. Astronomical theory of climate and the age of the Brunhes-Matuyama reversal. Earth Planet. Sci. Lett. 16, 91-108.

Bard, E., Ménot-Combes, G., Rostek, F., 2004. Radiocarbon calibration beyond $20000{ }^{14} \mathrm{C}$ yr b.p. by means of planktonic foraminifera of the Iberian margin. Quat. Res. 61, 204-214.

Bard, E., Delaygue, G., 2008. Comment on "Are there connections between earth magnetic field and climate? By Courtillot et al. Earth Planet. Sci. Lett. 265, 302-307.

Benson, L., Liddicoat, J., Smoot, J., Sarna-Wojcicki, A., Negrini, R., Lund, S., 2003. Age of the Mono lake excursion and associated tephra. Quat. Sci. Rev. 22, 135-140.

Berger, A., Loutre, M.F., 1991. Insolation values for the climate of the last 10 million years. Quat. Sci. Rev., 10, 297-317.

Berger, A., Loutre, M.F., 2002. An exceptionally long interglacial ahead? Science 23 (297), 1287-1288.

Biswas, D.K., Hyodo, M., Tanigucchi, Y., 1999. Magnetostratigraphy of Pio-Pleistocene sediments in a $1700 \mathrm{~m}$ core from Osaka Bay, Southwestern Japan and shor1 geomagnetic events in the middle Matuyama and the early Brunhes chrons. Palaeogeogr. Palaeoclimatol. Palaeoecol. 148, 233-248. 
Blanchet, C., Thouveny, N., de Garidel-Thoron, T., 2006. Evidence for multiple paleomagnetic intensity lows between 30 and $50 \mathrm{ka}$ BP from a western Equatorial Pacific sedimentary sequence. Quat. Sci. Rev. 25, 1039-1052.

Bonhommet, N., Babkine, J., 1967. Sur la présence d'aimantations inverses dans la Chaîne des Puys - Massif Central, France. Comptes rendus de l'Académie des Sciences. Paris, vol. 264, p. 92.

Bonhommet, N., Zahringer, J., 1969. Paleomagnetism and potassium argon age determinations of the Laschamp geomagnetic polarity event. Earth Planet. Sci. Lett., 6, 43-46.

Bullard, E.C., 1949. The magnetic field within the Earth. Proc. R. Soc. Lond., A 97, 433-453.

Carcaillet, J., Thouveny, N., Bourlès, D.L., 2003. Geomagnetic moment instability between 0.6 and 1.3 Ma from cosmonucleide evidence. Geophys. Res. Lett. 30 (15), 1792. doi: $10.1029 / 2003$ GL017550.

Carcaillet, J., Bourlès, D.L., Thouveny, N., Arnold, M., 2004a. A high resolution authigenic ${ }^{10} \mathrm{Be} /{ }^{9} \mathrm{Be}$ record of geomagnetic moment variations over the last $300 \mathrm{ka}$ from sedimentary cores of the Portuguese margin. Earth Planet. Sci. Lett. 219, 397-412.

Carcaillet, J., Bourlès, D.L., Thouveny, N., 2004b. Geomagnetic dipole moment and ${ }^{10} \mathrm{Be}$ Production rate intercalibration from authigenic ${ }^{10} \mathrm{Be} /{ }^{9} \mathrm{Be}$ for the last $1.3 \mathrm{Ma}$. Geochem. Geophys. Geosysts. 5, Q05006. doi:10.1029/2003/GC000641.

Champion, D., Dalrymple, G.B., Kuntz, M.A., 1981. Radiometric and paleomagnetic evidence for the Emperor reversed polarity event at $0.46 \pm 0.005$ Myrs in basalt lava flows from the eastern Snake River plain, Idaho. Geophys. Res. Lett. 8, 1055-1058.

Champion, D., Lanphere, Kuntz, M.A., 1988. Evidence for a new geomagnetic reversal from lava flows in Idaho: discussion of short polarity reversals in the Brunhes and late Matuyama polarity chrons. J. Geophys. Res. 93 (B10), 11667-11680.

Channell, J.E.T., 1999. Geomagnetic paleointensity and directional secular variation a1 Ocean Drilling Program (ODP) site984 (Bjorn drift) since $500 \mathrm{ka}$ : comparison with ODP site 983 (Gardar drift). J. Geophys. Res. 104 (B 10), 22937-22951.

Channell, J.E.T., 2006. Late Brunhes polarity excursions (Mono Lake, Laschamp, Iceland Basin and Pringle falls) recorded at ODP site 9191 (Irminger Basin). Earth Planet. Sci Lett. 244, 378-393

Channell, J.E.T., Hodell, D., McManus, J., Lehman, B., 1998. Orbital modulation of the Earth's magnetic field intensity. Nature 394, 464-468.

Channell, J.E.T., Stoner, Hodell, D.A., Charles, C., 2000. Geomagnetic paleointensity for the last 100 kyr from the subantarctic South Atlantic: a tool for interhemispheric correlation. Earth Planet. Sci. Lett. 175, 145-160.

Channell, J.E.T., Curtis, J.H., Flower, B.P., 2004. The Matuyama-Brunhes boundary interval (500-900 ka) in North Atlantic drift sediments. Geophys. J. Int. 158. 489-505

Chappell, J., 2002. Sea level changes forced ice breakouts in the last glacial cycle: new results from coral terraces. Quat. Sci. Rev. 21, 1229-1240.

Christl, M., Mangini, A., Kubik, P.W., 2007. Highly resolved Beryllium-10 record from ODP Site1089- a global signal? Earth Planet. Sci. Lett. 257, 245-258.

Christensen, U.R., Tilgner, A., 2004. Power requirement of the geodynamo from ohmic losses in numerical and laboratory dynamos. Nature 429, 169-171.

Coe, R.S., Liddicoat, J.C., 1994. Overprinting of natural magnetic remanence in lake sediments by subsequent high intensity field. Nature $367,57-59$.

Constable, C., Korte, M., 2006. Is the Earth's magnetic field reversing? Earth Planet. Sci. Lett. 246, 1-16.

Courtillot, V., Gallet, Y., Le Mouël, J.L., Fluteau, F., Genevey, A., 2007. Are there connections between the Earth magnetic field and climate? Earth Planet. Sci. Lett $253,328-339$

Courtillot, V., Gallet, Y., Le Mouël, J.L., Fluteau, F., Genevey, A., 2008. Response to the comment by Bard, E., Delaygue, G., 2008. on "Are there connections between earth magnetic field and climate? Earth Planet. Sci. Lett. 265, 308-311.

Creer, K.M., Readman, P., Jacobs, A.M., 1980. Palaeomagnetic and paleontological dating of a section at Gioia Tauro, Italy: identification of the Blake event. Earth Planet. Sci. Lett. 50, 289-300.

de Garidel-Thoron, T., Rosenthal, Y., Bassinot, F., Beaufort, L., 2005. Stable sea surface temperatures in the western Pacific warm pool over the past 1.75 million years Nature 433, 294-297.

Delprat, N., Escudie, B., Guillemain, P., Kronland-Martinet, R., Tchamitchian, P. Torresani, B., 1992. Asymptotic wavelet and Gabor analysis: extraction of instantaneous frequencies. IEEE Trans. Inf. Theory 38 (2), 644-664.

Demory, F., Nowaczyk, N.R., Witt, A., Oberhänsli, H., 2005. High-resolution magnetostratigraphy of late quaternary sediments from Lake Baikal, Siberia: timing of intracontinental paleoclimatic responses. Glob. Planet. Change 46, 167-186.

Denham, C.R., Cox, A., 1971. Evidence that the Laschamp polarity event did not occur 13300-30400 years ago. Earth Planet. Sci. Lett. 13, 181-190.

Doake, C.S.M., 1977. A possible effect of ice ages on the Earth's magnetic field. Nature 267, 415-417.

Elsasser, W., Ney, E.P., Winckler, J.R., 1956. Cosmic-ray intensity and geomagnetism. Nature $178,1226-1227$

Fabian, K., Hofmann, D.I., Frederichs, T., Hilgenfeldt, C., 2008. Correcting relative paleointensity records for compositional variation by automated discrete-sample sediment measurements on multiple cores. Geophys. Res. Abstr. 10, EGU2008-A05559 (EGU General Assembly 2008)

Fang, X.M., Li, J.J., Van der Voo, R., Mac Niocaill, C., Dai, X.R., Kemp, R.A., Derbyshire, E. Cao, Ji-Xiu, Wang, Jian-Ming, Wang Wang, Guo, 1997. A record of the Blake event during the last interglacial paleosol in the western plateau of China. Earth Planet Sci. Lett. 146, 73-82.

Fuller, M., 2006. Geomagnetic field intensity, excursions, reversals and the 41,000-yr obliquity signal. Earth Planet. Sci. Lett. 245 (3-4), 605-615.

Gee, J.S., Cande, S.C., Hildebrand, J.A., Donnelly, K., Parker, R.L., 2000. Geomagnetic intensity variations over the past $780 \mathrm{kyr}$ obtained from near-seafloor anomalies. Nature 408, 827-832.
Gillot, P.Y., Labeyrie, J., Laj, C., Valladas, G., Guerin, G., Poupeau, G., Delibrias, G., 1979. Age of the Laschamp geomagnetic polarity excursion revisited. Earth Planet. Sci. Lett. 42 $444-450$

Glatzmaier, G.A., Roberts, P.H., 1995. A three dimensional convective dynamo solution with rotating and finitely conducting inner core and mantle. Phys. Earth Planet Inter. 91, 63-75.

Guillemain, P., Kronland-Martinet, R., Martens, B., 1991. Estimation of spectral lines with the help of the wavelet transform: Applications in NMR spectroscopy. In "wavelet and application", Y. Meyer Ed, Masson \& Springer Verlag, 1991, 38-60.

Guillou, H., Singer, B., Laj, C., Kissel, C., Scaillet, S., Jicha, B.R., 2004. On the age of the Laschamp geomagnetic excursion. Earth Planet. Sci. Lett. 227, 331-343.

Guyodo, Y., Valet, J.P., 1996. Relative variations in geomagnetic intensity from sedimentary records: the past 200 ka. Earth Planet. Sci. Lett. 143, 23-26.

Guyodo, Y., Valet, J.P., 1999. Global changes in intensity of the Earth's magnetic field during the past 800 kyr. Nature 399, 249-252.

Guyodo, Y., Gaillot, P., Channell, J.E.T., 2000. Wavelet analysis of relative geomagnetic paleeointensity at ODP site 983. Earth Planet. Sci. Lett. 184, 109-123.

Henken-Mellies, W.U., Beer, J., Heller, F., Hsu, K.J., Shen, C., Bonani, G., Hofmann, H.J. Suter, M., 1990. ${ }^{10} \mathrm{Be}$ and ${ }^{9} \mathrm{Be}$ in South Atlantic DSPD Site 519: relation to geomagnetic reversals and to sediment composition. Earth Planet. Sci. Lett. 98, 267-276.

Herrero-Bervera, E., Helsley, C.E., Sarna-Wojcicki, A.M., Lajoie, K.R., Meyer, C.E., McWilliams, M.O., Negrini, R.M., Turrin, B.D., Donnelly-Nolan, J.M., Liddicoat, J.C., 1994. Age and correlation of a paleomagnetic episode in the western united states by Ar-40/Ar-39 dating and tephrochronology: the Jamaica, Blake or a new polarity episode? J. Geophys. Res. 99, 24091-24103.

Heslop, D., 2007. A Wavelet investigation of possible orbital influences on pas geomagnetic field intensity. Geochem. Geophys. Geosysts 8 (3), Q3003. doi:10 1029/2006GC001498.

Hofmann, D., Fabian, K., 2007. Rock magnetic properties and relative paleointensity stack for the last $300 \mathrm{ka}$ based on a stratigraphic network from the subtropical and subantarctic South Atlantic. Earth Planet. Sci. Lett. 260, 297-312.

Horng, C.-S., Roberts, A.P., Liang, W.T., 2003. A 2.14-million year astronomically-tuned record of relative geomagnetic paleointensity from the western Philippine Sea J. Geophys. Res. 108. doi:10.1029/2001JB001698.

Hulot, G., Eymin, C., Langlais, B., Mandea, M., Olsen, N., 2002. Small-scale structure o the geodynamo inferred from Oersted and Magsat satellite data. Nature 416 $620-623$.

Jin, R.-S., 1992. Cross correlation of the variations of the geomagnetic dipole moment and the fluctuations of Earth's rotation. J. Geophys. Res. 97, 17251-17260.

Kent, D.V., 1982. Apparent correlation of palaeomagnetic intensity and climatic records in deep-sea sediments. Nature $299,538-539$.

Kent, D.V., 1999. Orbital tuning of geomagnetic polarity time-scales. Philos. Trans. R. Soc. Lond. 357, 1995-2007.

Kent, D.V., Opdyke, N., 1977. Paleomagnetic field intensities recorded in Brunhes epoch deep sea sediment core. Nature 266, 156-159.

Kent, D.V., Carlut, J., 2001. A negative test of orbital control of geomagnetic reversals and excursions. Geophys. Res. Lett. 28, 3561-3564

Kent, D.V., Hemming, S.R., Turrin, B.D., 2002. Laschamp excursion at Mono lake? Earth Planet. Sci. Lett. 6121, 1-14.

King, J.W., Banerjee, S.K., Marvin, J., 1983. A new rock magnetic approach to selecting sediments for geomagnetic paleointensity studies: application to paleointensity for the last 4000 years. J. Geophys. Res. 88 (B7), 5911-5921.

Knudsen, M.F., Henderson, G.M., Frank, M., Mac Niocaill, C., Kubik, P., 2008. In-phase anomalies in Beryllium-10 production and palaeomagnetic field behaviour durin the Iceland Basin geomagnetic excursion. Earth Planet. Sci. Lett. 265, 588-599.

Laj, C., Kissel, C., Mazaud, A., Channell, J.E.T., Beer, J., 2000. North Atlantic paleointensity stack since $75 \mathrm{ka}$ (NAPIS-75) and the duration of the Laschamp event. Philos. Trans R. Soc. Lond. 358, 1009-1025.

Laj, C., Kissel, C., Beer, J., 2004. High resolution global paleointensity stack since $75 \mathrm{kyr}$ (GLOPIS-75) calibrated to absolute values. In: Channell, J.E.T., Kent, D.V., Lowrie, W Meert, J.G. (Eds.), Timescales of the Paleomagnetic Field. Geophysical Monograph vol. 145. American Geophysical Union, Washington, D.C

Lal, D., 1988. In: Castagnoli, G.C., Lal, D. (Eds.), Theoretically expected variations in the terrestrial cosmic-ray production rates of isotopes, in solar-terrestrial relation ships. Soc. Italiana di Fisica-Bologna-Italy, Bologna, pp. 216-233.

Lal, D., 1992. Expected secular variations in the global terrestrial production rate of radiocarbon. In: Bard, E., Broecker, W.S. (Eds.), The Last Deglaciation: Absolute and Radiocarbon Chronologies, Series I. Global Environmental Change, vol. 2 pp. 114-126

Langereis, C., Dekkers, M.J., de Lange, G.J., Paterne, M., van Santvoort, P.J.M., 2000 Magnetostratigraphy and astronomical calibration of the last $1.1 \mathrm{Myr}$ from an Eastern Mediterranean Piston core and dating of short events in the Brunhes. J. Geophys. Res. 129, 75-94.

Lanphere, M.A., 2000. Comparison of conventional K/Ar and ${ }^{40} \mathrm{Ar} /{ }^{39} \mathrm{Ar}$ dating of young mafic volcanic rocks. Quat. Res. 53, 294-301.

Leduc, G., Thouveny, N., Bourlès, D.L., Blanchet, C.L., Carcaillet, J.T., 2006. Authigenic Be10/Be9 signature of the Laschamp excursion: a tool for global synchronisation o paleoclimatic archives. Earth Planet. Sci. Lett. 245, 19-28.

Levi, S., Banerjee, S.K., 1976. On the possibility of obtaining relative paleointensities from lake sediments. Earth Planet. Sci. Lett. 29, 219-226.

Liddicoat, J.C., 1992. Mono Lake Excursion in Mono Basin, California, and at Carson Sink and Pyramid Lake, Nevada. Geophys. J. Int. 108, 442-452.

Liddicoat, J.C., 1996. Mono Lake Excursion in the Lahontan Basin, Nevada. Geophys. J. Int $125,630-635$

Liddicoat, J.C., Coe, R.S., 1979. Mono Lake geomagnetic excursion. J. Geophys. Res. 84 $261-271$ 
Liu, X.M., Liu, T.S., Liu, C., CHen, M.Y., 1988. The Chinese loess in Xifeng, I. The preliminary study on magnetostratigraphy of a loess profile in Xifeng area, Gansu Province. Geophys. J. Int. 92, 345-348.

Loper, D.E., 1975. Torque balance and energy budget for the precessionally driven dynamo. Phys. Earth Planet. Inter. 11, 43-60.

Lourens, L.J., Wehausen, R., Brumsack, H.J., 2001. Geological constraints on tidal dissipation and dynamical ellipticity of the Earth over the past three million years Nature 6823, 1029-1033.

Lund, S.P., Liddicoat, J.C., Lajoie, K.R., Henhey, T.L., Robinson, S.W., 1988. Paleomagnetic evidence for long-term $\left(10^{4}\right)$ memory and periodic behaviour in the Earth's core dynamo process. Geophys. Res. Lett. 15, 1101-1104.

Lund, S.P., Schwartz, M., Keigwin, L., Johnson, T., 2005. Deep-sea sediment records of the Laschamp geomagnetic field excursion (41,000 calendar years before present) J. Geophys. Res. 110. doi: 10.1029/2003JB002943.

Lund, S.P., Stoner, J.S., Channell, J.E.T., Acton, G., 2006. A summary of the paleomagnetic field variability recorded in Ocean Drilling Program Cores. Phys. Earth Planet. Inter 156, 194-204.

Malkus, W.V.R., 1963. Precessional torques as the cause of geomagnetism. J. Geophys. Res., 68, 2871

Malkus, W.V.R., 1968. Precession of the Earth's core as the cause of geomagnetism. Science 160, 259-264.

Martinson, D.G., Pisias, N.G., Hays, J.D., Imbrie, J., Moore, T.C., Shackleton, N.J., 1987. Age dating and the orbital theory of the ice ages: development of a high-resolution 0 to 300.000 year chronostratigraphy. Quat. Res. 27, 1-29.

Masson-Delmotte, V., Dreyfus, G., Braconnot, P., Johnsen, S., Jouzel, J., Kageyama, M. Landais, A., Loutre, M.-F., Nouet, J., Parrenin, F., Raynaud, D., Stenni, B., Tuenter, E. 2006. Past temperature reconstructions from deep-ice cores: relevance for future climate change. Climate of the Past 2, 145-165.

Mazaud, A., Sicre, M.A., Ezat, U., Pichon, J.J., Duprat, J., Laj, C., Kissel, C., Beaufort, L. Michel, E., Turon, J.L., 2002. Geomagnetic-assisted stratigraphy and sea surface temperature changes in core MD94-103 (Southern Indian Ocean): possible implications for North-South climatic relationships around H4. Earth Planet. Sci. Lett. 201, 159-170.

McWilliams, M., 2001. Global correlation of the 223 ka Pringle Falls Event. Int. Geol. Rev. 43, 191-195

Negrini, R.M., Davis, J.O., Verosub, K.L., 1984. Mono Lake geomagnetic excursion found at Summer Lake, Oregon. Geology 12, 643-646.

Negrini, R., Erbes, K.F., Herrera, A.M., Roberts, A.P., Cohen, A., Palacios-Fest, M., Wigand P.E., Foit, F., 2000. A paleoclimate record for the past 250,000 years from Summe Lake, Oregon, USA: I. Age control and magnetic lake level proxies. J. Paleolimnol. 24 125-149.

North Greenland Ice Core Project Members, 2004. High-resolution record of Northern Hemisphere climate extending into the last interglacial period. Nature 431,147-151

Nowaczyk, N.R., Frederichs, T.W., 1999. Geomagnetic events and relative paleointensity variations during the past 300 ka recorded in Kolbeinsey ridge sediments, Iceland sea: indication for a strongly variable geomagnetic field. Int. J. Earth Sci. 88, 116-131.

Oda, H., Nakamura, K., Ikehara, K., Nakano, T., Nishimura, M., Khlystov, O., 2002. Paleomagnetic record from Academician, ridge, Lake Baikal: a reversal excursion at the base of marine oxygen isotope stage 6. Earth Planet. Sci. Lett. 202, 117-132.

Peck, J., King, J.W., Colman, S.M., Kravchinsky, V.A., 1996. An 84 kyr paleomagnetic record from the sediments of Lake Baikal, Siberia. J. Geophys. Res. 101, 11365-11385.

Plenier, G., Valet, J.-P., Guérin, G., Lefèvre, J.-C., LeGoff, M., Carter-Stiglitz, B., 2007. Origin and age of the directions recorded during the Laschamp event in the Chaîne des Puys (France). Earth Planet. Sci. Lett. 259, 414-431.

Poincaré, H., 1910. Sur la précession des corps déformables. Bull. Astron. 27, 321-356.

Quidelleur, X., Gillot, P.Y., Carlut, J., Courtillot, V., 1999. Link between excursions and paleointensity inferred from abnormal field direction recorded at La Palma around 600 ka. Earth Planet. Sci. Lett. 168, 233-242

Raisbeck, G.M., Yiou, F., Bourlès, D., Kent, D.V., 1985. Evidence for an increase in cosmogenic ${ }^{10} \mathrm{Be}$ during a geomagnetic reversal. Nature $315,315-317$.

Raisbeck, G.M., Yiou, F., Bourlès, D.L., Lestringuez, J., Deboe, D., 1987. Measurements of ${ }^{10} \mathrm{Be}$ and ${ }^{26} \mathrm{Al}$ with a Tandetron AMS facility. Nucl. Instrum. Methods Phys. Res., B Beam Interact. Mater. Atoms 29, 22-26.

Raisbeck, G.M., Yiou, F., Cattani, O., Jouzel, J., 2006. ${ }^{10}$ Be evidence for the MatuyamaBrunhes geomagnetic reversal in the EPICA Dome C ice core. Nature 444, 82-84

Rampino, M.R., 1979. Possible relations between changes in global ice volume, geomagnetic excursions, and the eccentricity of the Earth's orbit. Geology 7, 584-587.

Roberts, A.P., Winklhofer, M., 2004. Why are geomagnetic excursions not always recorded in sediments? Constraints from post-depositional remanent magnetization lock-in modeling. Earth Planet. Sci. Lett. 227, 345-359.

Roberts, P.H., Wu, C., 2005. Precessionally-driven dynamo in a fluid layer. EOS Trans. AGU 86 (52).

Roberts, A.P., Winklhofer, M., Liang, W.-T., Horng, C.-S., 2003. Testing the hypothesis of orbital (eccentricity) influence on Earth's magnetic field. Earth Planet. Sci. Lett. 216 187-192.

Rochester, M.G., Jacobs, J.A., Smylie, D.E., Chong, K.F., 1975. Can precession power the geodynamo? Geophys. J. R. Astron. Soc. 43, 661-678

Roperch, P., Bonhommet, N., Levi, S., 1988. Paleointensity of the Earth's magnetic field during the Laschamp excursion and its geomagnetic implications. Earth Planet. Sci Lett. 88, 209-219.

Roucoux, K.H., Tzedakis, P.C., de Abreu, L., Shackleton, N.J., 2006. Climate and vegetation changes 180,000 to 345,000 years ago recorded in a deep-sea core off Portugal Earth Planet. Sci. Lett. 249, 307-325.

Ryan, W.B.F., 1972. Stratigraphy of late Quaternary sediments in the Eastern Mediterranean. In: Stanley, D.J. (Ed.), The Mediterranean Sea. Dowden, Hutchison and Ross, Stroudsberg, PA, pp. 149-169.
Saracco, G., 1994. Propagation of transient waves through a stratified fluid medium: wavelet analysis of a non-asymptotic decomposition of the propagator. J. Acoust. Soc. Am. 95 (3), 1191-1205.

Saracco, G., Gazanhes, C., Sageloli, J., Sessarego, J.P., 1990. Time-scale analysis of acoustic scattering by elastic spherical shells for impulse sources. J. Acoust. 3 (4), 381-392.

Saracco, G., Sessarego, J.-P., Sageloli, J., Guillmain, P., Kronland-Martinet, R., 1991. Extraction of modulations laws of elastic shells by the use of the wavelet transform. In: Meyer, Y. (Ed.), Wavelets and Applications. Masson-Springer, pp. 61-68.

Shackleton, N.J., Hall, M., Vincent, E., 2000. Phase relationship between millennial scales events 64.000-24.000 years ago. Paleoceanography 15, 565-569.

Shane, P., Black, T., Westgate, J., 1994. Isothermal plateau fission-track age for a paleomagnetic excursion in the Mamaku ignimbrite, New Zealand and implication for late Quaternary stratigraphy. Geophys. Res. Lett. 21, 1695-1698.

Singer, B.S., Relle, M.K., Hoffman, K.A., Battle, A., Guillou, H., Carracedo, J.C., 2002. Ar/Ar ages from transitionally magnetized lavas on La Palma, Canary Islands and the geomagnetic instability timescale. J. Geophys. Res. 107, 2307. doi:10.1029/2001JB001613.

Svensmark, H., Friis-Christensen, E., 1997. Variation of cosmic ray flux and global cloud coverage - a missing link in solar-climate relationships. J. Atmos. Sol.-terr. Phys. 59, 1225-1232.

Tauxe, L., 1993. Sedimentary records of relative paleointensity of the geomagnetic field: theory and practice. Rev. Geophys. 31, 319-354

Tauxe, L., Pick, T., Kok, Y., 1995. Relative paleointensity in sediments: a pseudo-Thellier approach. Geophys. Res. Lett. 22, 2885-2888.

Tauxe, L., Steindorf, J.L., Harris, A., 2006. Depositional remanent magnetization: toward an improved theoretical and experimental foundation. Earth Planet. Sci. Lett., 244, 515-529.

Tilgner, A., 2005. Precession Driven Dynamos, (ABS), 10th Scientific, Assembly IAGA

Thomson, J., Nixon, S., Summerhayes, C.P., Schönfeld, J., Zahn, R., Grootes, P., 1999. Implications for sedimentation changes on the Iberian margin over the last two glacial/interglacial transitions from $\left({ }^{230} \mathrm{Th} \text { excess }\right)_{0}$ systematics. Earth Planet. Sci. Lett. 165, 255-270.

Thouveny, N., 1987. Variations of the relative paleointensity of the geomagnetic field in western Europe in the interval 25-10 kyr BP as deduced from analyses of lake sediments. Geophys. J. R. Astron. Soc. 91, 123-142.

Thouveny, N., 1988. High resolution study of late Pleistocene sediments from Baffin Bay: first results. Can. J. Earth Sci. 25, 833-843.

Thouveny, N., Creer, K.M., 1992. Geomagnetic excursions in the last 60 thousand years: ephemeral secular variation features. Geology 20, 399-402.

Thouveny, N., Creer, K.M., Blunk, I., 1990. Extension of the Lac du Bouchet palaeomagnetic record over the last 120,000 years. Earth Planet. Sci. Lett. 97, 140-161.

Thouveny, N., Creer, K.M., Williamson, D., 1993. Geomagnetic moment variations in the last 70000 years: impact on the production of cosmogenic isotopes. Glob. Planet. Change 7, 157-172.

Thouveny, N., Moreno, E., Delanghe, D., Candon, L., Lancelot, Y., Shackleton, N.J., 2000 Rock-magnetic detection of distal Ice Rafted Debries: clue for the identification of Heinrich layers on the Portuguese margin. Earth Planet. Sci. Lett. 180, 61-75.

Thouveny, N., Carcaillet, J., Moreno, E., Leduc, G., Nérini, D., 2004. Geomagnetic moment variation and paleomagnetic excursions during the past $400 \mathrm{ka}$ : a stacked record from sedimentary cores of the Portuguese margin. Earth Planet. Sci. Lett. 219, $377-396$.

Tric, E., Laj, C., Valet, J.P., Tucholka, P., Paterne, M., Guichard, F., 1991. The Blake geomagnetic event: transition geometry, dynamical characteristics and geomagnetic significance. Earth Planet. Sci. Lett. 102, 1-13.

Tucker, P., 1981. Paleointensity from sediments: normalisation by laboratory redepositions. Earth Planet. Sci. Lett. 56, 398-404

Tzedakis, P.C., 2005. Towards an understanding of the response of southern European vegetation to orbital and suborbital climate variability. Quat. Sci. Rev. 24,1585-1599 2005

Valet, J.P., 2003. Time variations in geomagnetic intensity. Rev. Geophys. 41, 1-44

Valet, J.-P., Meynadier, L., 1998. A comparison of different techniques for relative paleointensity. Geophys. Res. Lett. 25, 1, 89-92.

Vanyo, J.P., 1991. A geodynamo powered by luni-solar precession. Geophys. Astrophys. Fluid Dyn. 59, 209-234.

Vanyo, J.P., 2004. Core-mantle relative motion and coupling. Geophys. J. Int. 158, 470-478.

Vanyo, J.P., Dunn, J.R., 2001. Core precession flow, structure and energy. Geophys. J. Int. $142,409-425$

Vlag, P., Thouveny, N., Williamson, D., Rochette, P., Ben-Atig, F., 1996. Evidence for a geomagnetic excursion recorded in the sediments of Lac St. Front, France: a link with the Laschamp excursion? J. Geophys. Res. 101 (B12), 28211-28230.

Wagner, G., Beer, J., Laj, C., Kissel, C., Masarik, J., Muscheler, R., Synal, H.-A., 2000. Chlorine 36 evidence for the Mono Lake event in the summit GRIP ice core. Earth Planet. Sci. Lett. 181, 1-6.

Williams, T., Thouveny, N., Creer, K.M., 1998. A normalised intensity record from Lac du Bouchet: geomagnetic paleointensity for the last 300 ka? Earth Planet. Sci. Lett. 156, 33-46.

Wilson, D.S., Hey, R.N., 1980. The Galapagos axial magnetic anomaly: evidence for the Emperor reversal within the Brunhes and for a two-layer magnetic source. Eos 61, 943.

Worm, H.U., 1997. A link between geomagnetic reversals and events and glaciations. Earth Planet. Sci. Lett. 147, 55-67

Xuan, C., Channell, J.E.T., 2006. Testing the relationship between timing of geomagnetic reversals/excursions and phase of orbital cycles using circular statistics and Monte Carlo simulations. Earth Planet. Sci. Lett. 268, 245-254.

Xuan, C., Channell, J.T., 2007. A wavelet approach of determining the origin of orbital periods in relative paleointensity records. Eos Trans. AGU 88 (52) (Fall Meet. Suppl., Abstract GP43A-0931) 
Yamazaki, T., Oda, H., 2002. Orbital influence on Earth's magnetic field: 100,000-year periodicity in inclination. Science 295, 2435-2438.

Yokoyama, Y., Yamazaki, T., 2000. Geomagnetic paleointensity variation with a $100 \mathrm{kyr}$ quasi-period. Earth Planet. Sci. Lett. 181, 7-14.

Yokoyama, Y., Yamazaki, T., Oda, H., 2007. Geomagnetic 100-ky variation extracted from paleointensity records of the equatorial and North Pacific sediments. Earth Planets Space 59, 795-805
Zic, M., Negrini, R., Wigand, P.E., 2002. Evidence of synchronous climate change across the Northern Hemisphere between the North Atlantic and the northwestern Great Basin, United States. Geology 30, 635-638.

Zimmerman, S.H., Hemming, S.R., Kent, D.V., Searle, S.Y., 2006. Revised chronology for late Pleistocene Mono Lake sediments based on paleointensity correlation to the global reference curve. Earth Planet. Sci. Lett. 252, 94-106. 